Magdalena Piotrowska

https://doi.org/10.26485/AAL/2020/66/10

\title{
PUBLIC OR PRIVATE? \\ AN ATTEMPT TO INTERPRET THE SOCIAL-ECONOMIC PURPOSE AND DIFFERENCES BETWEEN WELLS LOCATED ON A PRZEWORSK CULTURE SETTLEMENT (BASED INTERDISCIPLINARY RESEARCH - EXAMPLE OF THE SITE IN KWIATKÓW) ${ }^{1}$
}

\begin{abstract}
The aim of this article is to present the results of the archaeological analysis carried out on two wells from the site Kwiatków 11/20 (Brudzew commune, Greater-Poland Voivodeship) against a background of the geochemical and lithological data, as well as to outline the lithological and geological conditions of the surroundings of the excavated area. Within this settlement more than 100 wells were recorded. Most of the wells discovered have features of the Przeworsk culture from the first centuries AD. The analysis and interpretation of the data obtained (thanks to interdisciplinary research) helps us to understand the validity of use and functions of the wells within the site mentioned, and their social aspects. Thanks to the cooperation of specialists representing various scientific fields, it was possible to identify some differences not only in the chronology of both fields analyzed, but also in their function within the area of the settlement.
\end{abstract}

Keywords: Przeworsk culture, Roman Period, settlement, wells, interdisciplinary researches

\author{
WSPÓLNE CZY PRYWATNE? \\ PRÓBA INTERPRETACJI RÓŻNIC ORAZ FUNKCJI SPOŁECZNO-GOSPODARCZYCH \\ STUDNI ZLOKALIZOWANYCH W PRZESTRZENI OSADY KULTURY PRZEWORSKIEJ \\ (NA PODSTAWIE BADAŃ INTERDYSCYPLINARNYCH - PRZYKŁAD STANOWISKA W KWIATKOWIE)
}

ABSTRAKT Celem tego artykułu jest przedstawienie wyników analizy archeologicznej przeprowadzonej dla dwóch studni ze stanowiska Kwiatków 11/20 (gmina Brudzew, województwo wielkopolskie) na tle danych geochemicznych i litologicznych, a także zarysowanie warunków litologicznych i geologicznych w otoczeniu przebadanego obszaru. W obrębie prezentowanej osady zarejestrowano ponad 100 studni, z których większość łączona jest z osadnictwem kultury przeworskiej z pierwszych wieków naszej ery. Analiza i interpretacja uzyskanych danych (dzięki interdyscyplinarnym badaniom) pomaga zrozumieć zasadność kopania studni, ich funkcje oraz ich kontekst społeczny. Dzięki współpracy specjalistów reprezentujących różne dziedziny udało się uchwycić pewne różnice nie tylko w chronologii obu analizowanych obiektów, ale także w ich funkcji w przestrzeni osadniczej.

Słowa kluczowe: kultura przeworska, okres rzymski, osadnictwo, studnie, badania interdyscyplinarne

Introduction

The location and development of centres of settlement in prehistory depended, in many cases, on the availability of a supply of water, as well as

1 The subject and the course of the research were financed from the budget of the National Science Centre granted as part of financing the internship after obtaining the doctoral degree based on the decision number DEC-2015/16/S/HS3/00241. the presence of soils suitable for cultivation and good communications. The Kwiatków site is located on the confluence of the River Warta with smaller watercourses. Thanks to its location, the area under analysis was rich in natural sources of water during the settlement's existence. Large river valleys provide lithologically diverse areas developing soils of varying, and often high, usefulness and productivity.

The site in Kwiatków is a vast (extending over several hectares) long-lasting settlement of the Przeworsk culture, where most of the materials 


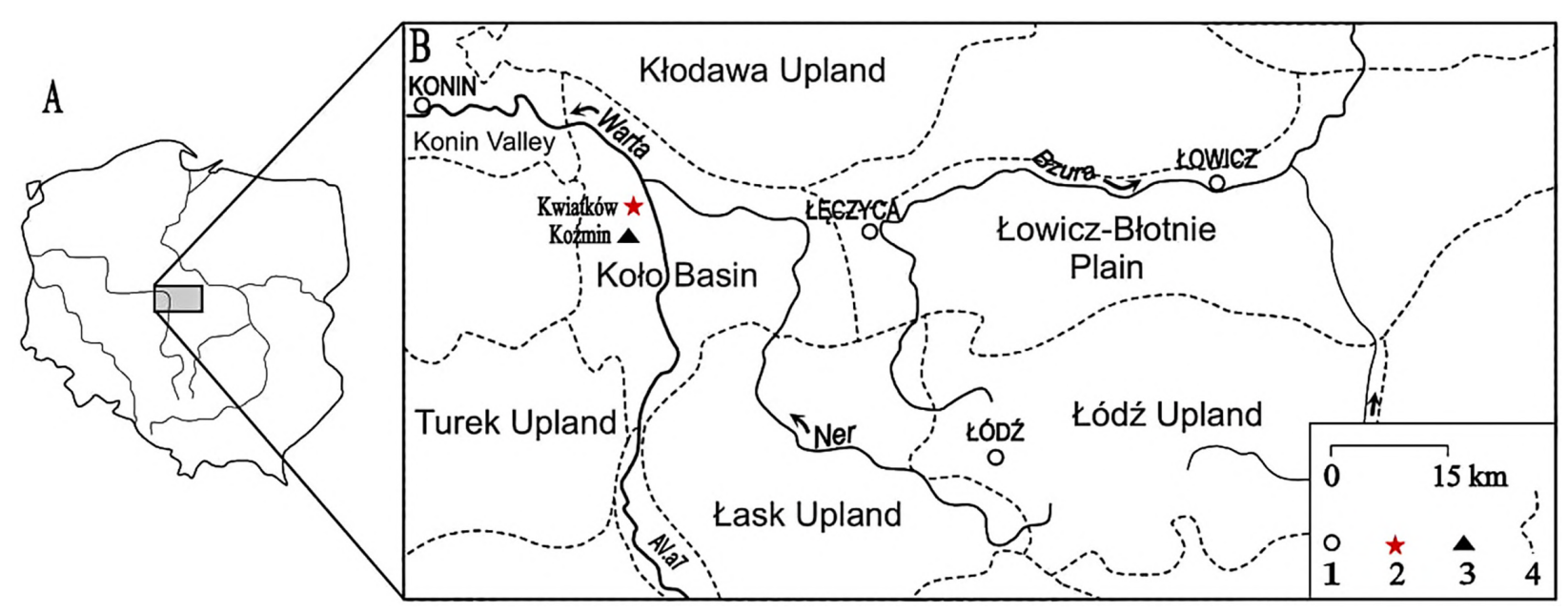

Fig. 1. Location of the site - Kwiatków 11/20, Brudzew commune. A - Location on the territory of Poland, B - Location of Kwiatków on the background of geomorphological typology of Poland (Gilewska 1986). 1 - selected cities, 2 - Kwiatków site 11,3-Koźmin-Las site, 4 - boundaries of geomorphological units (by J. Forysiak and J. Twardy in Piotrowska, Okupny, Forysiak, Twardy 2019, 56, Fig. 1)

recovered, according to the current state of our knowledge, can mainly be dated to the Roman Period, particularly to the first centuries AD. During several seasons of research, a large number of wells were recorded belonging mainly to this period. In total, about 100 were discovered, most of which contained fairly well-preserved, lower parts of wooden casings. ${ }^{2}$ Such a high number of wells distinguishes Kwiatków from other settlements of the Przeworsk culture. The rationale for building so many of them in an area adjacent to natural watercourses is a compelling issue. Perhaps the wells discovered in Kwiatków had various functions and different social contexts. This is indicated, among other things, by their distribution within the settlement, and their functional relationships with other features. ${ }^{3}$

Geochemical and lithological tests were but some of several specialised analyses conducted on the wells from Kwiatków, which were aimed at reconstructing the environment in the vicinity of the site, and attempted to address the question of why there were so many wells in a settlement whose hydrographic resources were so abundant. The area was particularly attractive for settlement, because one of the courses of the "Amber Route", an ancient trade route, ran through it.

The aim of this article is to present the results of the archaeological analyses carried out on two wells from the site Kwiatków 11/20 (Brudzew commune) against the background of the geochemical

2 I.e. Rzepecki et al. 2016: 59, 73-82; Piotrowska 2016: 63-95.

3 See Piotrowska 2019; Piotrowska in press. and lithological data, as well as to outline the lithological and geological conditions of the area surrounding that excavated. Analysis and interpretation of the data obtained thanks to interdisciplinary research helps us to understand the differences between these features, the reasons for their use, and their social function within the site mentioned. It should be emphasized that this article will focus on the archaeological context, and that the specialised interdisciplinary analysis complementing has already been published in detail elsewhere ${ }^{4}$.

\section{The Area under Study}

The site of Kwiatków is located in Brudzew Commune, Greater-Poland Voivodeship. The site lies in the central part of the geomorphological mesoregion of the Koło Basin. This region is classified as part of the Southern Wielkopolska Lowland ${ }^{5}$ (Fig. 1). The Koło Basin the zone lying between two main landforms: the longitudinally-oriented Warta river valley and the latitudinal running Warsaw-Berlin Urstromtal. The area of the Koło Basin underwent glaciation during the Wartanian glaciation, and the penultimate glaciation of the Quaternary. ${ }^{6}$ During the Weichselian glaciation, the glacial margin reached the north-west edge of the basin (Fig. 1) and crossed the Warta valley to the west of the town of Koło. ${ }^{7}$ The area under study

\footnotetext{
4 See Piotrowska, Okupny, Twardy, Forysiak 2019.

5 Gilewska 1986: 32.

6 Klatkowa 1972.

7 Petera, Forysiak 2003.
} 


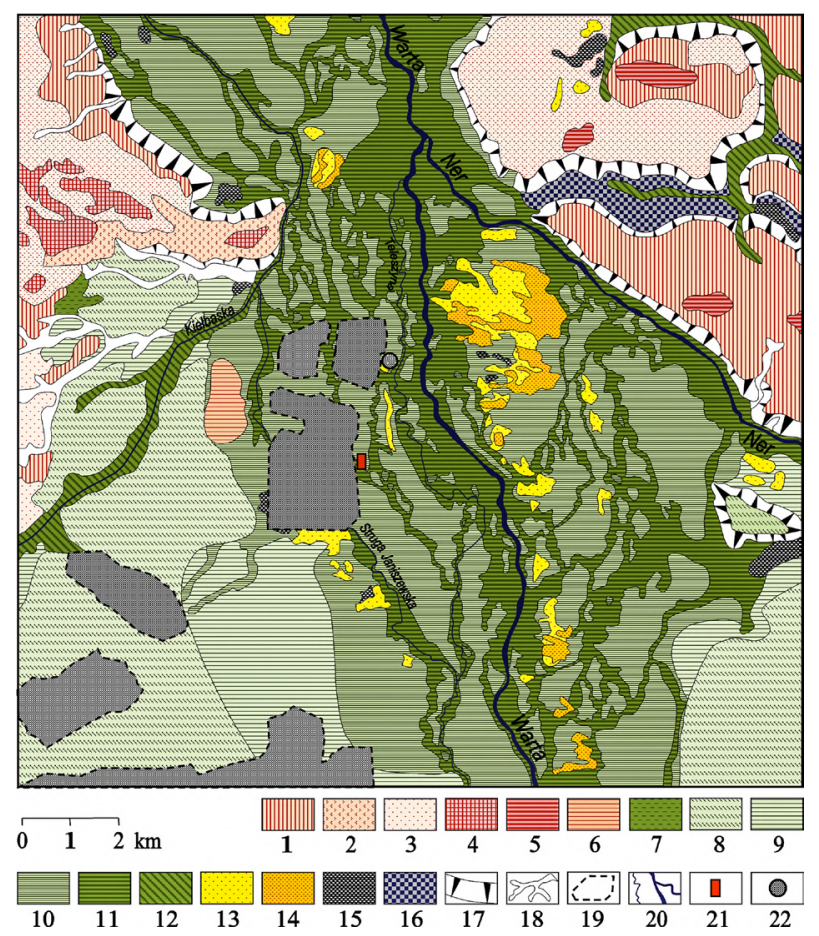

Fig. 2. Geomorphological map of central part of Koło Basin (after Forysiak 2005, partly changed). 1 - morainic plateau, 2 - morainic, hummocky plateau, 3 - glaciofluvial plain, 4 - terminal morains, 5 - kames, 6 - erosional terrace, 7 - floor of inactive valley, 8 - low level of marginal valley, 9 - high terrace, 10 - low terrace, 11 - valley floor of Warta river system,

12 - valley floor other rivers, 13 - aeolian plain, 14 - dunes, 15 - peatlands, 16 - pool-water plain, 17 - slopes, 18 - denudational valleys, 19 - post-mining areas (outcrops, heaps, reclaimed areas, etc.), 20 - larger river channels, 21 - Koźmin-Las site, 22 - Kwiatków 11/20 site (by J. Forysiak and J. Twardy in Piotrowska, Okupny, Forysiak, Twardy 2019, 57, Fig. 2)

has been shaped for over 100,000 years by fluvial and aeolian processes. These processes occurred both under periglacial climatic conditions (during the last glaciation) and in temperate climatic conditions (during the Eemian interglacial and the Holocene). The relief of the bottom of the Koło Basin, including in the vicinity of the Kwiatków site, has the character of a plain. Two terrace levels are visible in the relief (Fig. 2), as well as narrow valley floors. ${ }^{8}$ The site of Kwiatków is located in an area in between two channels, delineated to the east by the valley of the Teleszyna river, and to the west by the shallow valley of the Siedza river, and to the south by a dry channel connecting small unnamed watercourses. The central part of the site

Petera 2002; Forysiak 2005. of Kwiatków is heightened by 1-2 $\mathrm{m}$ by an aeolian cover, or the remnants of a small, irregular dunes. ${ }^{9}$

A hydrological node functioned in the Koło Basin. It is formed mainly by the Warta and Ner rivers, but also by many other watercourses which have been previously mentioned. In prehistory the area was characterised by an abundance of flowing water, and a stable, shallow, and thus easily accessible, ground water table. Ground water reservoirs were constantly fed by precipitation and numerous water courses flowing concentrically into this basin. ${ }^{10}$

Description of the analysed features wells 2581 and 2555

Both wells selected for specialized geochemical analyses were located in zone A1 of the site ${ }^{11}$ which is situated the north-eastern part of the area surveyed, in the vicinity of the rivers Warta and Teleszyna (Fig. 3, Fig. 4).

Features 2581 and 2555 are wells with fairly well-preserved wooden casings of log construction. In the case of the first feature, dendrochronological analyses provided dates for almost all the laths or planks used for building the casing (Fig. 5). The chronological range of this well (based on several dates) was decisive for selecting this feature for detailed specialised analyses. The second well was selected for in-depth research in order to compare the results obtained for the former feature. Both wells had casings constructed in the same way, but their location in the settlement, and the content of their fills showed significant differences, which makes these features all the more interesting in the light of the geochemical analyses which were conducted on them.

Feature 2581 was located in the central part of zone A1 (Fig. 3, Fig. 4). No features with determined function, related to the Przeworsk culture were recorded in its immediate vicinity, except for what might be the remains of a small ditch (?). As mentioned above, it is the well for which no less than 16 dendrochronological dates were obtained (Fig. 5). These dates point mainly to the first half of

9 Twardy 2016.

10 Analysis of natural environment around the site in Kwiatków, including hydrogeological conditions was part of the grant no. DEC-2015/16/5/HS3/00241 financed from the National Science Center. These studies were headed by prof. J. Twardy from the University of Lodz; Twardy et al. 2017.

11 see: Rzepecki 2016: 8. 


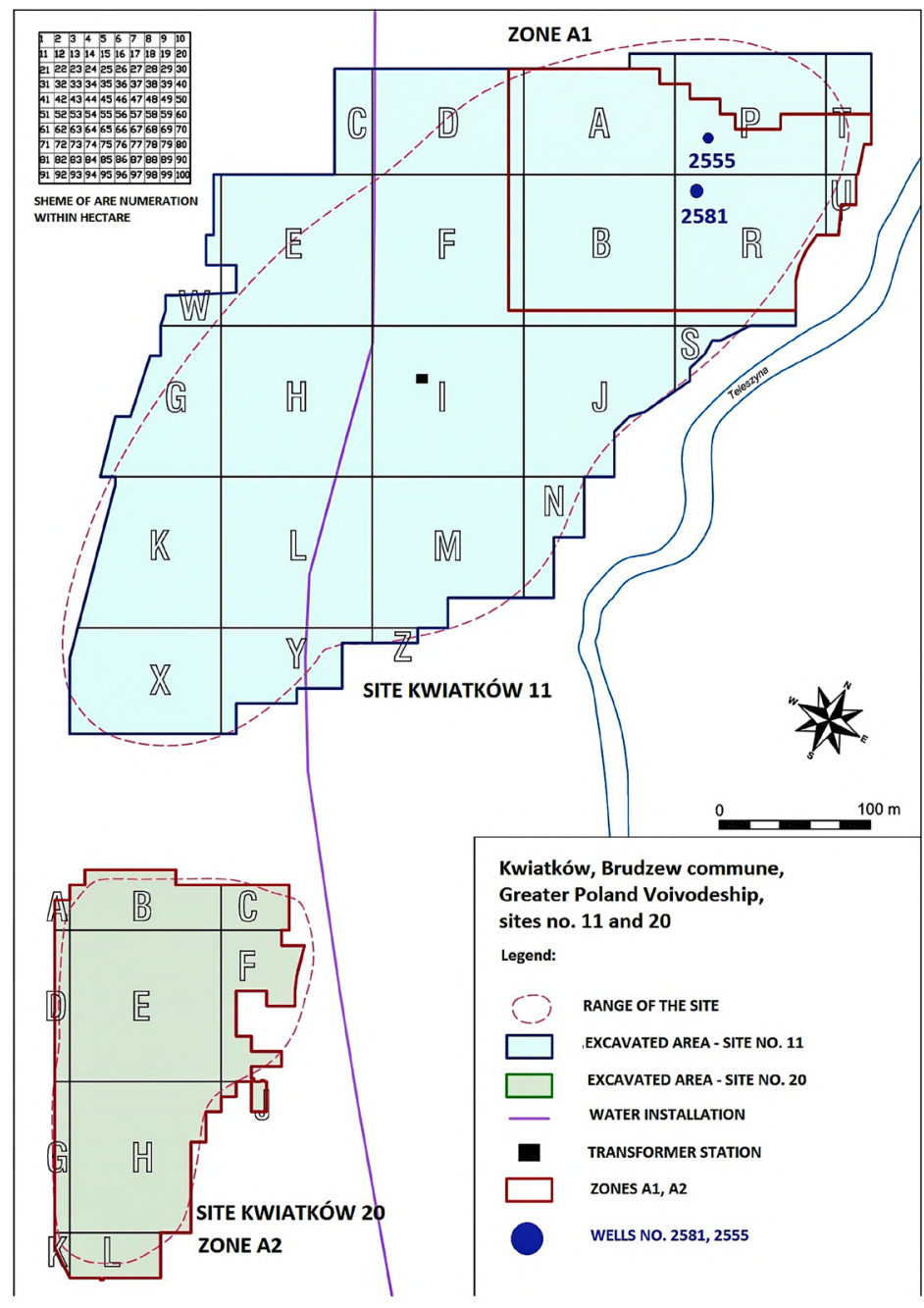

Fig. 3. Kwiatków 11/20, Brudzew commune: range of the site, excavated area, zones A1 and A2, location of the wells no. 2555 and 2581 (M. Piotrowska after Rzepecki 2016, 7; fig. 2 with some changes and Piotrowska, Okupny,

Forysiak, Twardy 2019, 58, Fig. 3)

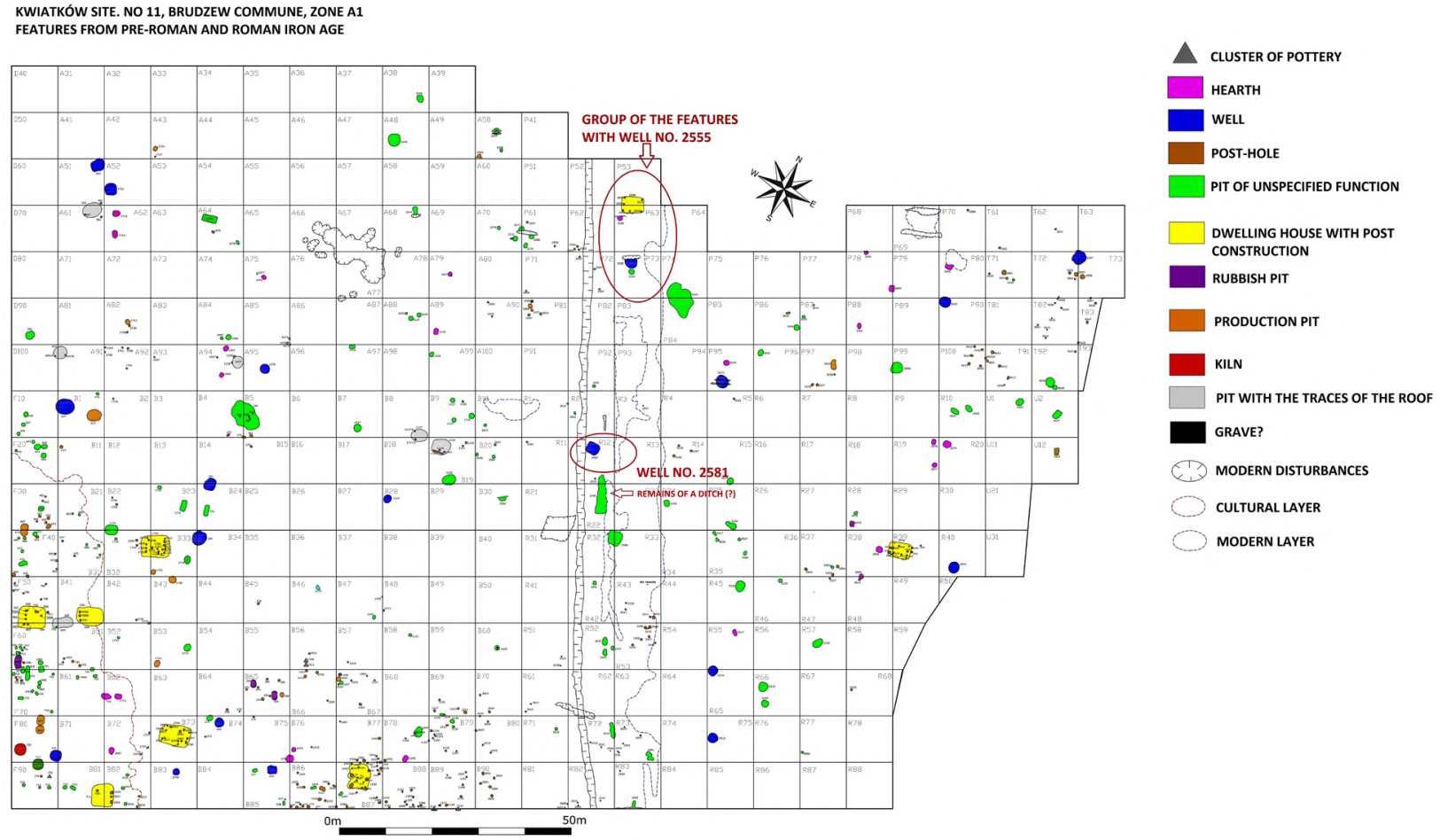

Fig. 4. Kwiatków 11/20 Brudzew commune, zone A1.

Features from pre-roman and roman Iron Age

(M. Piotrowska after Rzepecki 2016 ed. with some changes) 


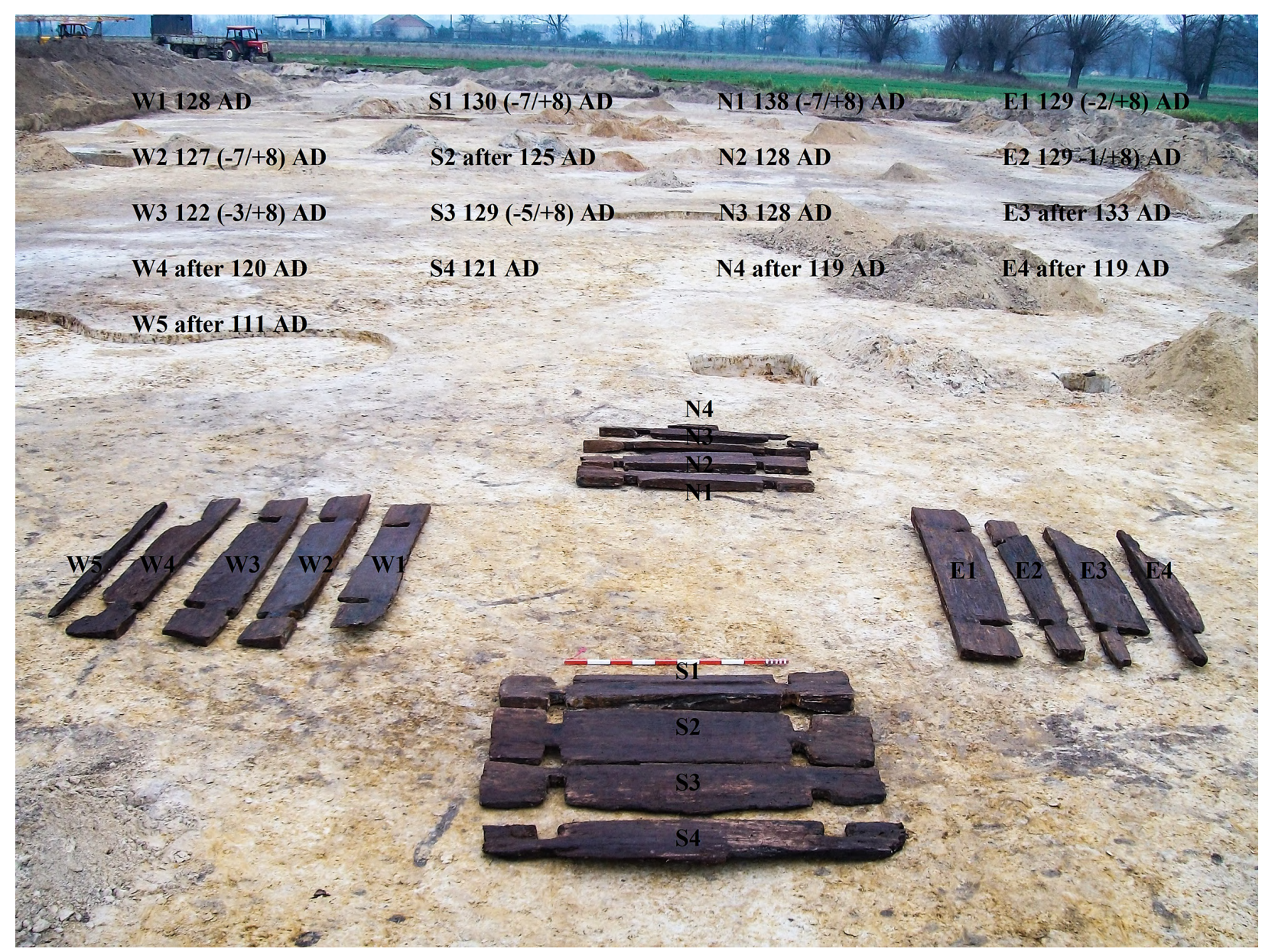

Fig. 5. Kwiatków 11/20, Brudzew commune.

Dendrochronological dates obtained from the planks of log construction well no. 2581 (by M. Piotrowska)

the 2nd century AD. The precise dates are AD 121, AD 128, circa AD 122, AD 127, AD 129-130 AD and $\mathrm{AD}$ 138. Oak was the material used for making the casing. ${ }^{12}$

The casing was constructed from logs (Fig. 6). Its preserved height was about $1 \mathrm{~m}$ and the width was about $1.1 \mathrm{~m}$ (with extensions up to $1.9 \mathrm{~m}$ ). The preserved wooden structure was found at the depth of about $1 \mathrm{~m}$ from the trench surface, which suggests that the original depth of the well was about 2 $\mathrm{m} .{ }^{13}$ The base of the well was discovered at a depth of $93.55 \mathrm{~m}$ a.s.1. and it cut into an organic layer identified with the horizon of the fossil forest. ${ }^{14}$

A total of 48 pottery fragments were recorded in the feature. The whole cluster is linked to the Przeworsk culture from the Roman Period. Nondiagnostic sherds predominated which were unsuitable for reconstructing the original vessel form.

12 Krapiec 2016: 359-361.

13 Piotrowska 2016: 71.

14 Petera-Zganiacz et al. 2019.
A single, almost entirely preserved vessel discovered at the bottom of the well was an exception; its location and state of preservation indicate that it entered the interior of the feature when the well was still in use (Fig. 7). The vessel is a vase with a biconical body and a vertical rim, with a rounded, non-thickened lip ${ }^{15}$. At its widest part the body measured $1 / 3$ of its height. The bottom of the vessel had a rough surface, but its upper part, i.e. the short, vertical neck and the shoulder, are smooth (Fig. 8). The surface of the vessels found in well 2555 are treated in a similar way (see below). Vaseshaped vessels similar to the one recovered from the feature under discussion come from the burial site in Oblin which is dated to the early phase of the Roman Period ${ }^{16}$ and from the funerary complex in Ciebłowice Duże, dated to phase $\mathrm{C} 1 \mathrm{a}^{17}$. Such

5 Kot 2016: 154.

16 Czarnecka 2007: 54, 354; tab. 190; grave 220B:

1.

17 Dzięgielewska, Kulczyńska 2008: 24, 153; tab. 43; grave 57: 15 . 


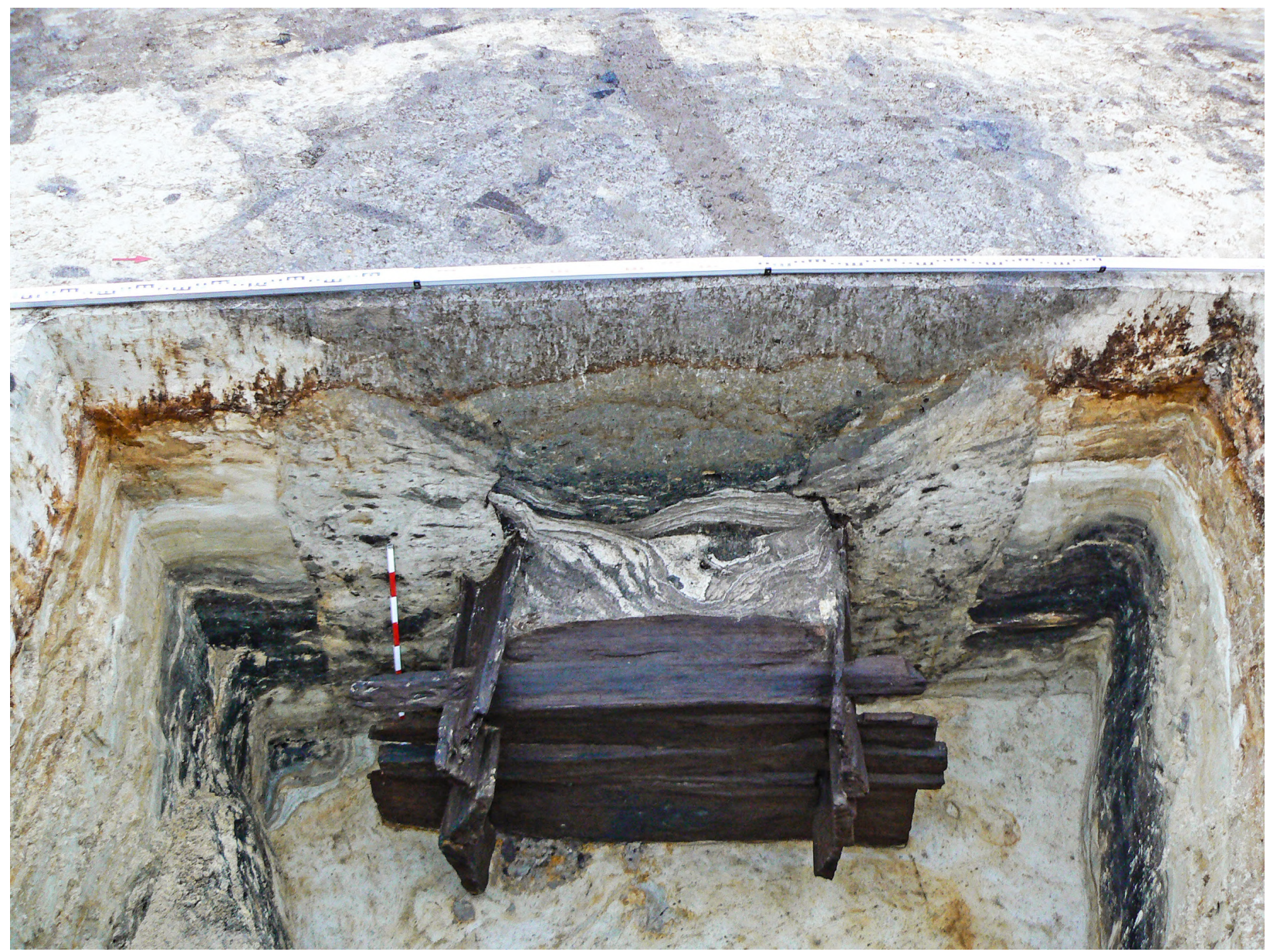

Fig. 6. Kwiatków 11/20, Brudzew commune. Well no. 2581 (phot. E. Schellner)

vases are known mainly from funerary complexes dated from phase B2 to C2. ${ }^{18}$ Vase-shaped vessels similar to the one from the feature 2581 were also recorded in other wells excavated in Kwiatków. This type of vessel was probably used for drawing water up from wells (Fig. 7). ${ }^{19}$

In addition, a container (basket/bucket?) made of bark was recorded in this feature, which might have been used to store food in the well. ${ }^{20}$ There were also single animal bones recorded, only 3 , which were identified as coming from cattle (Waszczuk 2016, annex 1; table 11).

Feature 2555 was located in the northern part of zone A1, on the edge of the area being researched (Fig. 3, Fig. 4). Unfortunately, it proved impossible to determine the dates when the trees used for the construction of the casings were cut down by means of dendrochronological analyses. Only the identification of the wood type was possible: oak, just as in the case of the first well. The chronology

18 Machajewski 1995: 12, 70; tab. 1: 5.

19 Piotrowska 2019a.

20 Piotrowska 2016: 72; Piotrowska in press. of feature 2555 was determined on the basis of the artefacts obtained from the fill, and on the basis of the dates obtained for the half-dugout dwelling 2590 (a shallow pithouse with posts fixed in the earth, the main method of housing construction used at this site). The well was located in the vicinity of this feature and was functionally connected with it. This half-dugout constructed of six posts fixed in the earth, of which fragments consisting of the lower parts beneath the ground were preserved. At present this is the only building from the site from which wooden constructional elements are preserved. Dates of shortly after AD 119, and after AD 129 AD were obtained by dendrochronological analyses. ${ }^{21}$ Feature 2555 also had a casing of $\log$ construction whose preserved height was about $1.2 \mathrm{~m}$ and the width of the "chest" was about $1.2 \mathrm{~m}$ (about $1.4 \mathrm{~m}$ at its widest extent) (Fig. 9). The casing was found at a depth of about $0.7 \mathrm{~m}$ from the excavation surface and its hypothetical depth was almost $2 \mathrm{~m}$. The bottom of the feature was recorded at a depth of $93.40 \mathrm{~m}$ a.s.1. and it was 


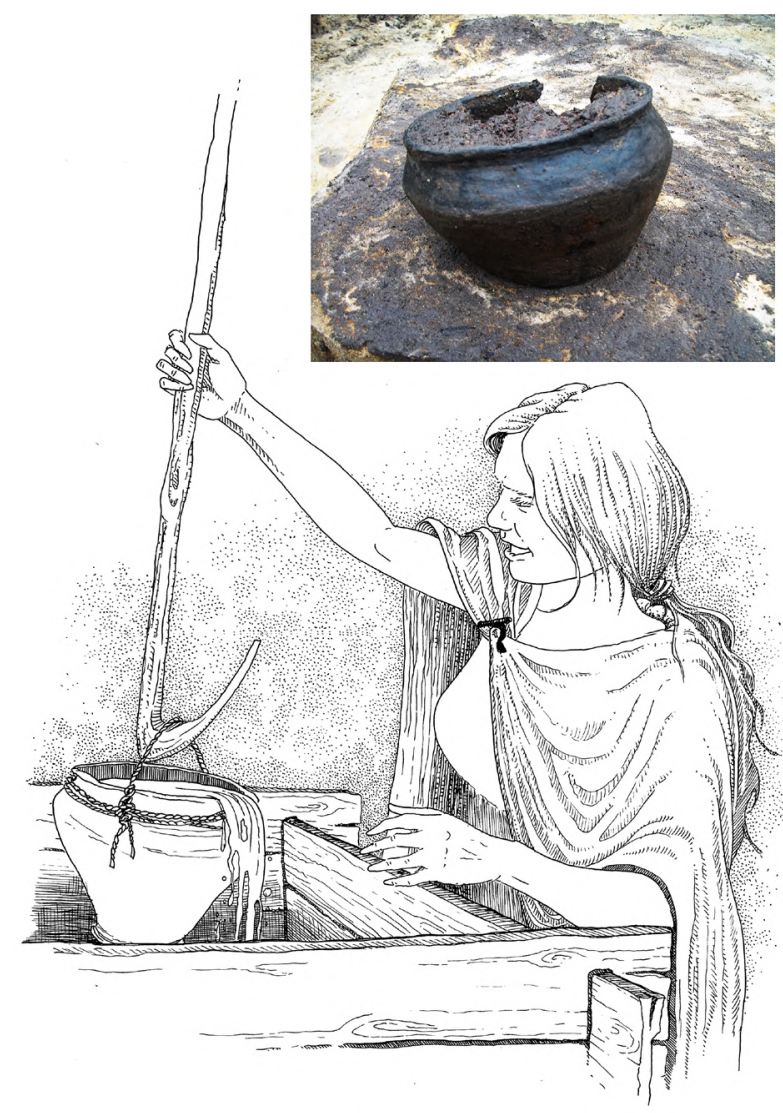

Fig. 7. Kwiatków 11/20, Brudzew commune. Vessel from well no. 2581 in situ (phot. E. Schellner) and artictic reconstruction of drawing water from well

(drawn by M. Wiechno) (M. Piotrowska with some changes after Piotrowska 2019a, Ryc. 5)

also "anchored" in the organic layer - the remains of the fossil forest. At the base of this feature, four planks arranged side by side were recorded. ${ }^{22}$ Their presence can be explained by the intention to protect the well against silting.

The artefacts obtained from the well mainly comprised fragments of vessels. In total 99 fragments were recorded. The sherds found in the fill located above the preserved wooden construction were mainly small fragments, of which 27 were identified as belonging to the earlier pre-Roman Period, and 34 belonging to the Roman Period. Among the older ones, only one fragment was suitable for the partial reconstruction of the original vessel (Fig. 10: 1). It was the upper part of a vase with a vertical rim which had a thickened lip, bevelled from the top. ${ }^{23}$ Thanks to its distinct neck, this vessel fragment can be linked to phase A3 of the earlier pre-Roman Period ${ }^{24}$. An analogy to

\footnotetext{
22 Piotrowska 2016: 71.

23 Kot 2016, 143; Kot, Piotrowska 2016: 289.

24 Dąbrowska 1988: 36.
}

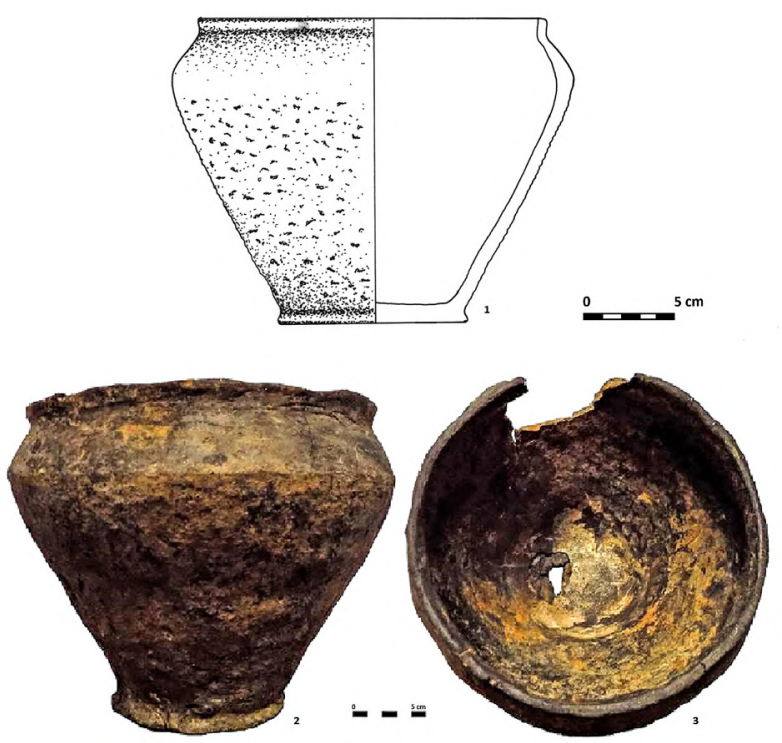

Fig. 8. Kwiatków 11/20, Brudzew commune. Vessel from well no. 2581 (bottom part of the feature) (by M. Piotrowska).

this vessel with its accentuated neck can be found in the assemblage of pottery from the necropolis in Oblin. The tomb which the similar artefact was found is dated to phase A3 of the earlier pre-Roman Period ${ }^{25}$. The lower part of the fill of the casing contained pottery from the Roman Period: in all 34 fragments, of which only 3 fragments date to the earlier pre-Roman Period. The older fragments, i.e. those connected with the Przeworsk culture, from the end of the earlier pre-Roman Period, occurred in the secondary context of the feature. The casing yielded fragments of vessels dating back to the Roman Period, including the upper part of a vase similar to the vessel found in well 2581. Its surface was treated similarly except that in this case the surface of the vase is rough up to the area of its shoulder (Fig. 10: 2). The rim is slightly turned outward, and the lip is rounded and bevelled from the top. This form in the upper part of the vessel indicates phases B1-B2 of the Roman Period. ${ }^{26} \mathrm{~A}$ vessel with roughened surface which was almost identical to the vase currently under discussion comes from the necropolis in Oblin, already mentioned before, and is dated to phase B2 of Roman Period ${ }^{27}$. Such forms are mainly found in phase B2 or, less frequently, in phase B1 of the Roman Period. ${ }^{28}$ Another burial

25 Czarnecka 2007: 58, 59, 373; tab. 209; grave: 248: 18

26 Liana 1970: 493.

27 Czarnecka 2007: 65, 401; tab. 237; grave 288: 13.

28 Liana 1970: 439. 


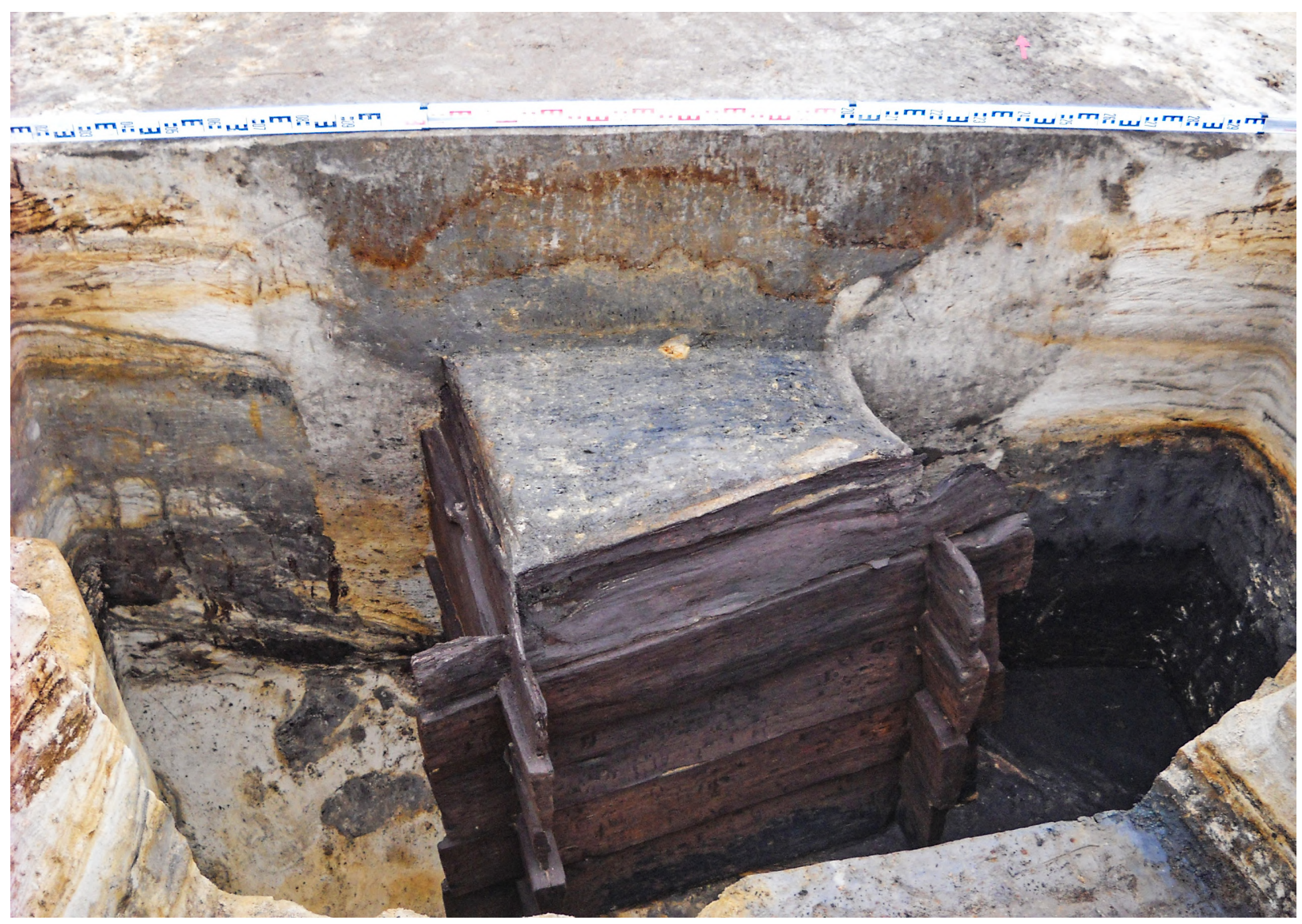

Fig. 9. Kwiatków 11/20, Brudzew commune. Well no. 2555 (phot. E. Schellner)

ground which yielded a similar vessel in the funerary complex dating back to phase $\mathrm{B} 2 \mathrm{~b}$, which is located in Ciebłowice Duże. ${ }^{29}$ The assemblage of pottery obtained from the fill of casing also included a bottom (Fig. 10: 3), which was probably a part of the vase already discussed, and the upper part of a bowl (Fig. 10: 4). The vessel, which is classified as a bowl, has a biconical body and vertical rim with rounded, non-thickened lip. ${ }^{30}$ Such vessel forms are mainly found in phase B2 or, less frequently, in phase B1 of the Roman Period. ${ }^{31}$

The well also contained 14 animal bones. Among them, bovine bones (7) bearing traces of hacking and biting by predators, and some remains of small ruminants (5) dominated. ${ }^{32}$ Single fragments belonging to horse and dog were found too. A fragment of a canine jawbone lacking teeth and with closed sockets seems worth noting here. ${ }^{33}$

29 Dziegielewska, Kulczyńska 2008: 16, 123; tab. 13; grave 17: 7 .

30 Kot 2016: 143.

31 Liana 1970: 439.

32 Waszczuk 2016: annex 1; table 17.

33 Waszczuk 2016: annex 1; table 10.
The lower and middle sections of the fill of the well contained fragments of wood probably originating from the upper part of the casing which had collapsed inwards.

Research methods and characteristic of the analysed sediments

As stated in the introduction, in addition to discussing the formal characteristics of both features, and the analysis of the archaeological material sampled from their fillings, specialized geochemical and lithological analyses were also carried out. ${ }^{34}$ The research methods applied have already been presented in detail elsewhere and thus are only outlined in brief here. ${ }^{35}$

34 Analysis were part of the grant no. DEC2015/16/5/HS3/00241 financed from the National Science Center Lithological analysis was carried out by prof. J. Forysiak from University of Lodz and geochemical one by Dr. D. Okupny from Pedagogical University in Cracow.

35 See Piotrowska, Okupny, Twardy, Forysiak 2019: 58-60; Piotrowska, Forysiak in press. 

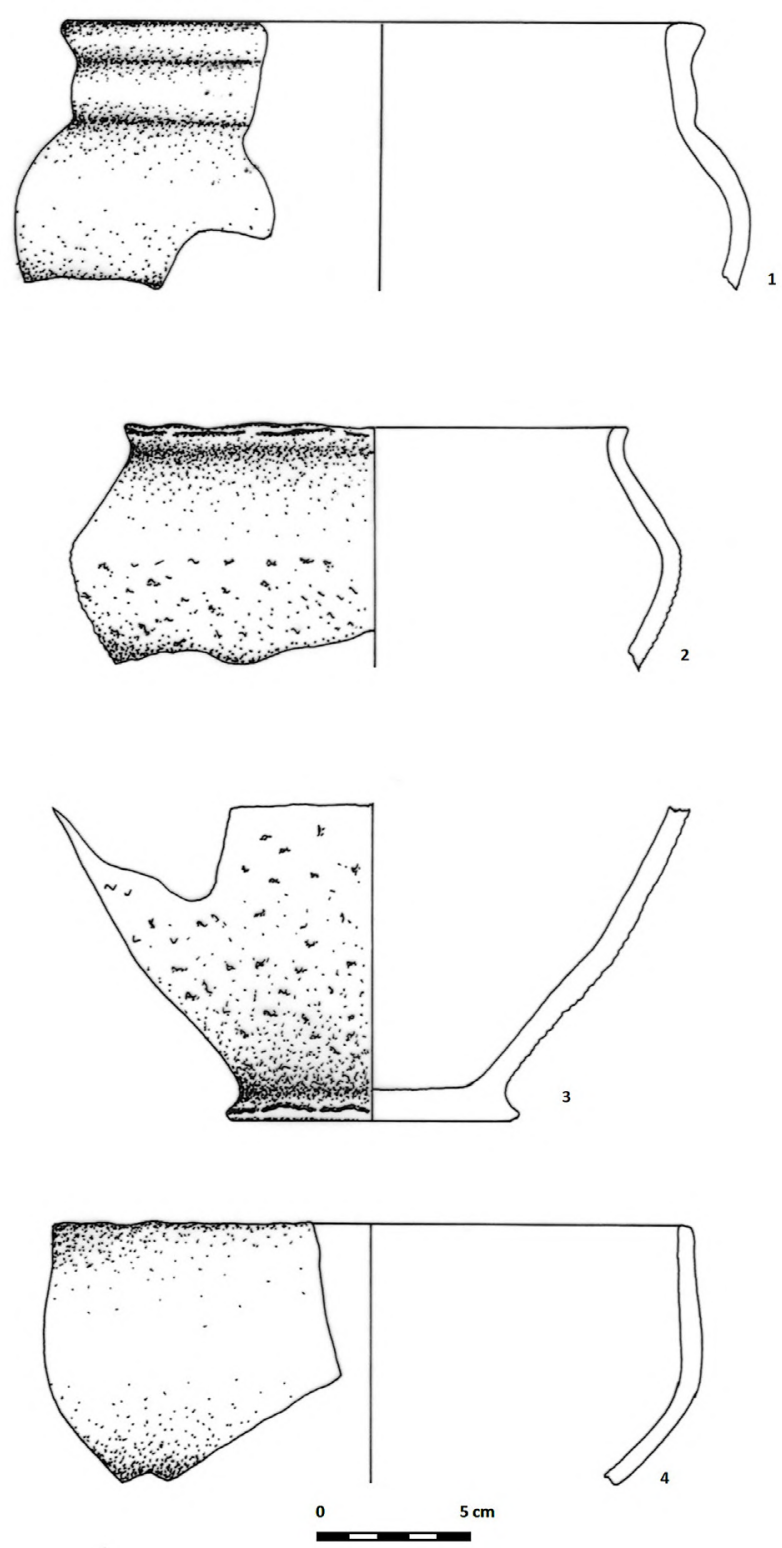

Fig. 10. Kwiatków 11/20, Brudzew commune. Pottery from well no. 2555 (1 - VIII mechanical layer; 2-4 - fill of the preserved wooden construction) (by M. Piotrowska).

The material for analysis was obtained as "cores" taken from the lower parts of the fill of the casings. The material from well 2581 was analysed first. Samples from the other feature, well 2555, were also tested in order to compare the results obtained for both wells. Samples of sediments from the fills of two wells, in the case of well 2581 a thickness of $83 \mathrm{~cm}$, and $126 \mathrm{~cm}$ in the case of well 2555 were subjected to detailed lithological and geochemical analyses. ${ }^{36}$ The cores were divided into sections of from 2 to $5 \mathrm{~cm}$ : a total of

36 Piotrowska, Okupny, Twardy, Forysiak 2019:

Fig. 4.
56 samples. During laboratory work, grain size distribution was carried out as well as the identification of basic litho-geochemical components, and the concentration of selected elements.

Both wells were filled by sand and silt containing organic matter. Based on the vertical variation of the geochemical and lithological features, we can distinguish 3 (for well 2581) and 4 (for well 2555) geochemical zones in the vertical deposit's succession. For feature 2581 three geochemical levels were determined on the basis of a distinct variability in the content of lithophilic elements $(\mathrm{K}, \mathrm{Mg}, \mathrm{Na})$ whose contribution initially rises, and in the top part, an increase of organic content may be observed. In the case of feature 2555 , all four geochemical levels are characterised by a notably lower diversity of the distribution of specific mineral fractions and the content of the studied elements. ${ }^{37}$

Detailed analysis indicated that the deposits making up the fills of this profile are clearly different in terms of geochemical composition, and percentage share of mineral fractions. These differences can probably be the result of non-simultaneous time-filling processes of the wells. Although the average concentrations of marked litho-geochemical components for both profiles are similar, in the case of the well 2581, the values of the coefficient of variation, calculated as the ratio of the mean to the standard deviation, are twice as high. ${ }^{38}$

The mineral components making up the fills could thus be delivered to the well as slope-wash by waters flowing from the slopes of a low hill in the middle of the archaeological site, or surface fluvial water wash and aeolian processes. The results of the lithological analyses showed differences in the grain size composition of the material forming the fills of both wells and material making up the area of the site. They indicate that the finegrained silt and silty material that was deposited into the well, came from outside the site, because the sediment composition of the surroundings of the wells mainly involved relatively well sorted sand. It has a textural similarity to the fine-grained fluvial sediments of the Warta river, examined by J. Petera ${ }^{39}$ and J. Forysiak. ${ }^{40}$ Silt and silty clay in the fill of the well most likely came from erosion and washing till and glacial-genic deposits

37 Piotrowska, Okupny, Twardy, Forysiak 2019: 59, 60, 64 .

38 Piotrowska, Okupny, Twardy, Forysiak 2019: 67.

39 Petera 2002.

40 Forysiak 2005. 
in the undercut channel of the Warta river, or the smaller rivers: the Teleszyna and Siedza. They were accumulated in the wells during floods, which covered the bottom of the shallow valley of the Teleszyna river and the lower parts of its slopes. ${ }^{41}$

Location of wells in the area of the settlement and their function

As indicated, both features utilize the same technique of the casing construction (Fig. 11). Log casings prevailed in zone A1, which should not be surprising given that the $\log$ technique was the most common one used for casing wells during the Roman Period. ${ }^{42}$ However, there is a clear difference in the presence of the planks at the bottom of feature 2555 as well as the location context, in the case of both wells, in the settlement's space and their social function. As mentioned before, the first well (2581) was located in the central part of zone $\mathrm{A} 1$, in the area where not many other "accompanying" features of the Przeworsk culture were recorded which could be precisely dated and precisely defined functionality, except for feature which could have been a ditch. ${ }^{43}$ The case of the second well 2555 is diverse. It is clearly visible that this feature was located "at the back" of the half-dugout building 2590, which was accompanied by a hearth and other "Przeworsk-related" features (Fig. 4). Feature 2555 had an element of one of the clear functional "systems" which have been distinguished within zone A1. It was a model "complex" of features which did not raise any doubts on account of some isolation from other features dated to the Roman Period. ${ }^{44}$ The "core" of such a complex of features, in this case, was the half-dugout building with posts set in the earth 2590. In the West German settlement zone, features of this type are referred to as "dugouts with six posts". ${ }^{45}$ In the classification of structures of this type proposed by A. Michałowski, the feature falls into the sub-type B. ${ }^{46}$ The building had its long side facing the east-west axis. Outside this feature, in its south-western corner, there was a hearth and a well located about $9 \mathrm{~m}$ south of the building.

41 See Twardy 2016; Piotrowska, Okupny, Twardy, Forysiak 2019.

42 Nowakowski, Waluś 1986; Piotrowska 2016: 92, 93.

43 Kot, Piotrowska 2016: 294.

44 Kot, Piotrowska 2016: 295; Piotrowska 2019:

138; Piotrowska, Okupny, Twardy, Forysiak 2019: 67.

45 Zimmermann 1992: 158.

46 Michałowski 2011: 118-122; tab. 5.

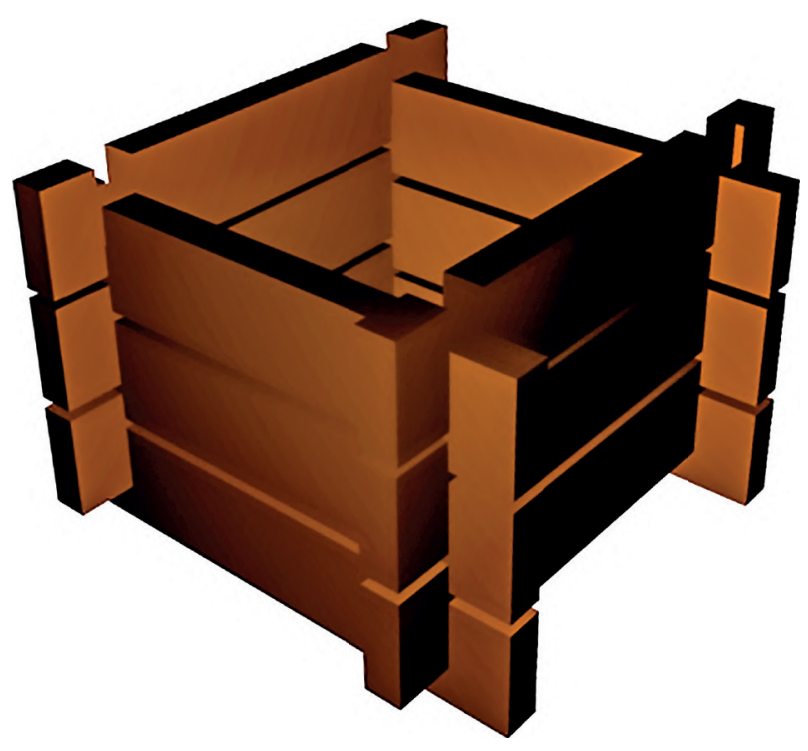

Fig. 11. Reconstruction of the log casing in which, both of the analysed features were constructed (by M. Michałowicz)

The purpose of the aforementioned half-dugout seems a compelling issue which could bring us closer to the function of the well 2555. In the earlier specialist literature, such features were mainly treated as residential. ${ }^{47}$ Currently, it is sometimes argued that these features served as independent workshops, e.g. used for weaving purposes..$^{48}$ It is believed that these structures were places of specialised production due to their favourable conditions such as temperature and humidity ${ }^{49}$ However, the aforementioned residential function cannot be excluded here, especially during the winter period, when the smaller area enclosed by the half-dugout was easier to heat. ${ }^{50}$ This type of small buildings without housing for livestock, which have been interpreted as various craft workshops, are known from sites in Feddersen Wierde, or Tornow, for example. ${ }^{51}$ Settlements based on agriculture were characterised by some elements related to specialized production. In the settlement in Janków, Piątek commune, an attempt was made to single out some "complexes" of features which consisted of dugout buildings and wells, and sometimes also of constructions above ground with posts set in the earth, and household refuse pits. ${ }^{52}$ Wells were located in the vicinity of the majority of the dugouts

47 Godłowski 1981: 105; Jadczykowa 1981: 190-

194; Kobyliński 1988: 17-22.

48 Michałowski 2011: 164.

49 Stapelfeld 2000: 74.

50 Michałowski 2011: 163.

51 Jankuhn 2004: 114.

52 Jurkiewicz, Machajewski 2006: 136. 
and the above-ground post structures. Such an arrangement of features occurred in two out of three zones, which were identified within the settlement, where zones were characterized by a linear arrangement of the features. The occurrence of the well in Janków could be related to the existence of farmsteads within the settlement. ${ }^{53}$ An analogous "arrangement of features" to the settlement being currently discussed was recorded at the site Sługocinek 13, Golina commune. The log well was found there in the immediate vicinity of a small building constructed of posts. ${ }^{54}$ It seems that the settlement there displayed similar features to the site in Kwiatków, however, the complexes of features are more visible in the case of the Kwiatków settlement.

The different location and function of the two wells in the area of the settlement in Kwiatków is also reflected in the amount, and the character of the material obtained from their fills (see above). Feature 2581 yielded much less pottery than well 2555. In the second mentioned feature, one fully preserved vessel was found (probably connected with drawing water) (Fig. 7, Fig. 8) and some single, non-diagnostic fragments. In well 2555 , the number of pottery as well as the number of partly reconstructed forms was higher (Fig. 10). This is probably related to the location of this well near the half-dugout (2590) and other features related to the culture being studied. Hence, the fragments of bones and the larger amount of pottery entering the well from the surrounding area had been more intensively used by the inhabitants of Kwiatków. Apparently, despite the relative closeness of the two features, about $35 \mathrm{~m}$ separate wells 2581 and 2555, their content and purpose are different, as well as the social context in which they were located.

From the first century AD onwards wells became more important and were more frequently built. However, little information about the function of these wells and their location within the area of settlements has been provided by excavations, and therefore study of the social aspect of these features has usually been omitted also. Wells may have been common property. There are wells that cannot be clearly assigned to individual farmsteads. The question arising from this is whether these were "public" wells, available to all residents of the settlement? On the other hand the irregular positioning of these wells within the sites,

53 Skowron 2014: 115

54 Krzyszowski 2012: 145, 152; fig. 3.
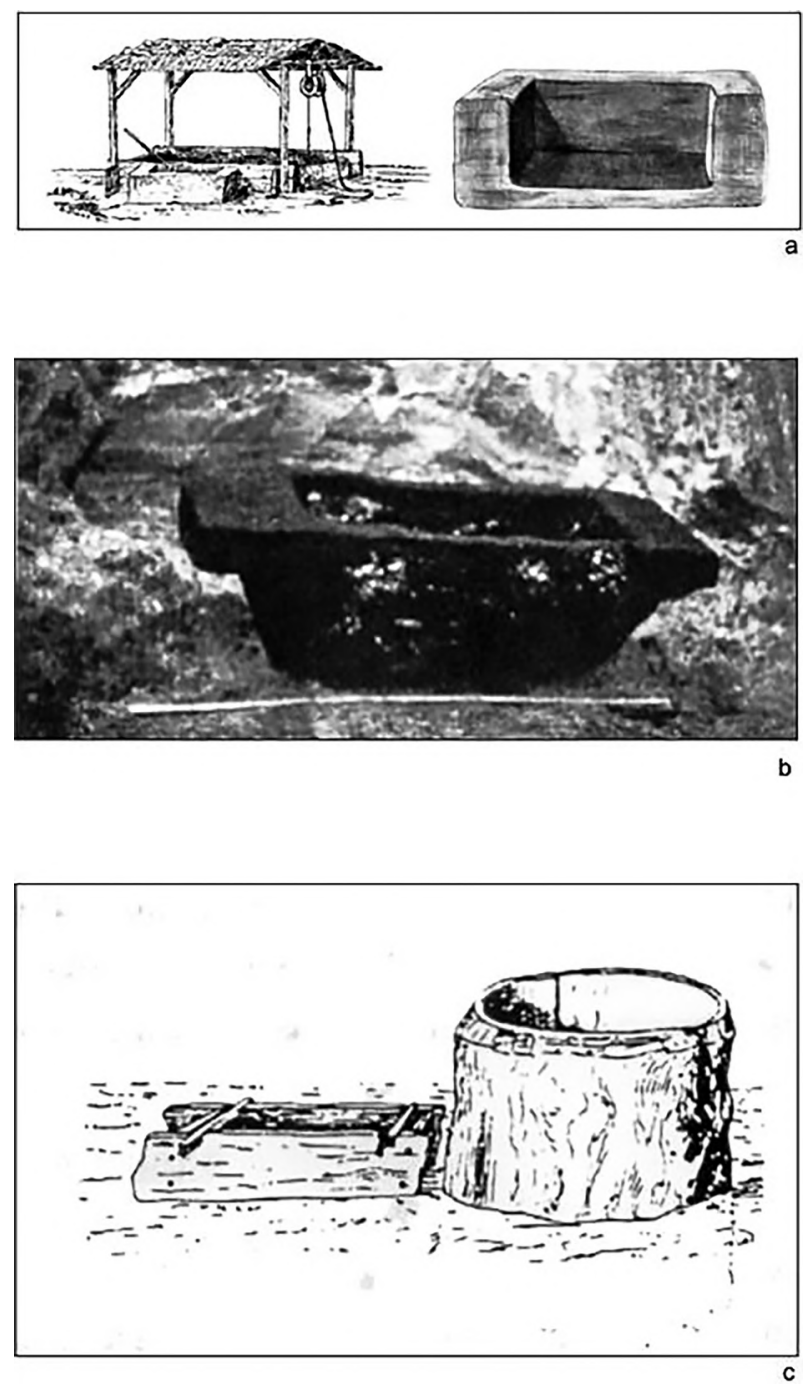

Fig. 12. a: reconstruction of the well and trough from Donnstetten (after Schmidt 2003, 94, Abb.31);

b: trough from Stickenbüttel found in the well (after Schmidt 2003, 95, Abb. 32);

c: well of the hollowed tree trunk and the trough (after Gaude 1995, 61, Abb. 24)

can be the basis for assigning them to particular farmsteads located in their immediate vicinity. ${ }^{55}$

The different location of the two wells in the settlement in Kwiatków could be related to their different functions. Feature 2581 can be described as a common, "public" well and 2555 as a "private" well; evidently functionally connected with the half-dugout 2590. The well "belonging" to the small building was undoubtedly somehow connected with it, regardless of whether feature 2590 was a workshop requiring direct access to water, or a small residential half-dugout, or whether it was a building combining both of the functions mentioned. The planks at the base of well 2555 might have

55 See Leube 2009: 162. 


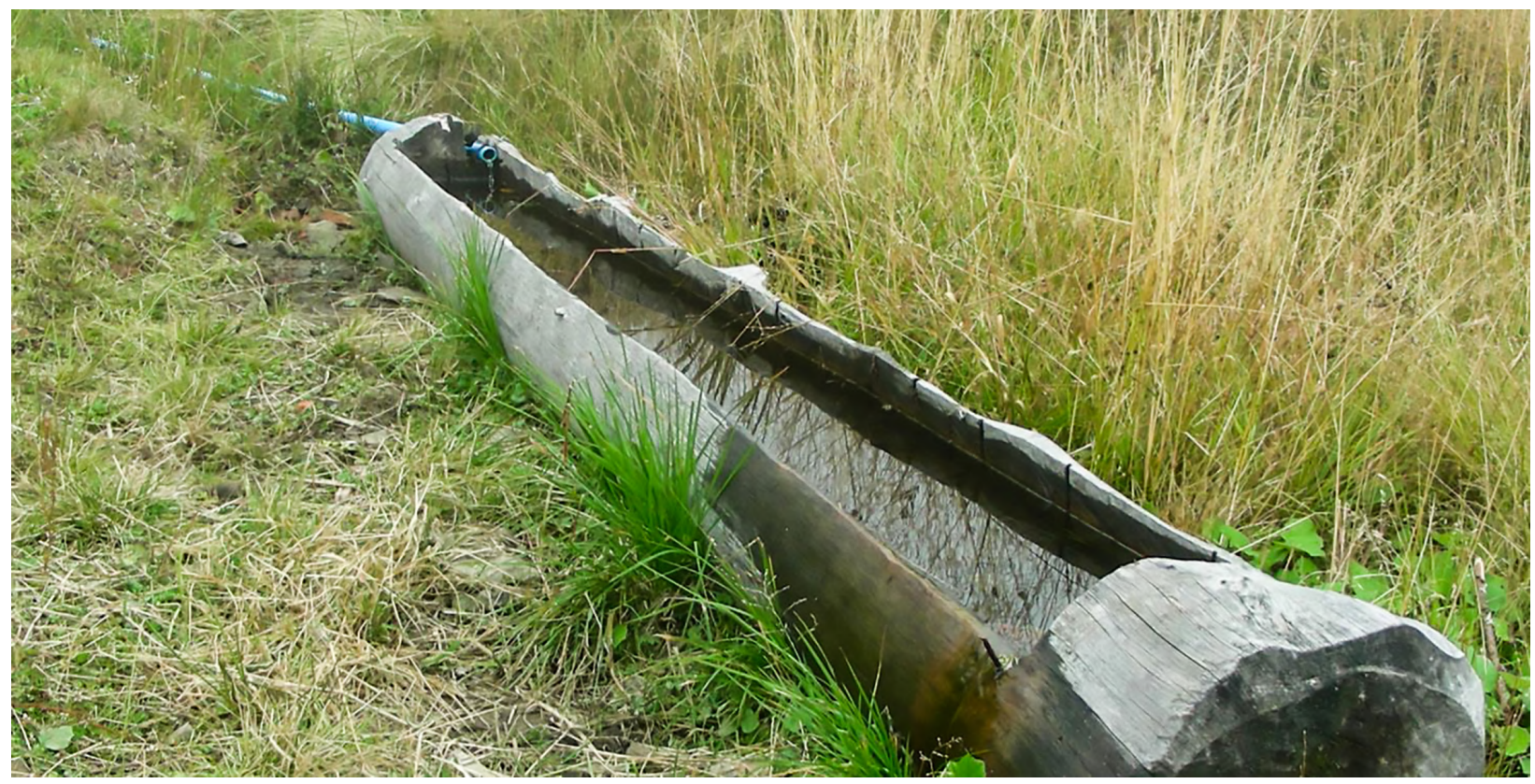

Fig. 13. The trough for sheep, Żywiec Beskids

(http://katowice.rdos.gov.pl/czy-beskidzkie-owce-beda-mialy-co-pic)

prevented the stirring of mud when drawing water which was for drinking. In this way the consumers of this water were trying to improve the quality of the water. To the contrary feature 2581 might have been associated with the supply of water for animals bred by the inhabitants of Kwiatków. Hence its fill contained far fewer artefacts, which are numerous in the wells associated with, for example, half-dugouts or the ones located in those settlement zones which were intensively used. They are consequently also richer in artefacts.

Wells of a "private" nature are noted less frequently in settlements of the Przeworsk culture, although in Kwiatków they appeared in large numbers in association with half-dugouts. ${ }^{56}$ Wells belonging to small shallow pit houses with structures incorporating posts were located at a distance of up to $10 \mathrm{~m}$ from them, usually to their eastern or southern sides.

The house is a social unit and at the same time a unit of domestic production, which is also part of its identity. ${ }^{57}$ To give a comparative example, in settlements from the Netherlands, late Roman Iron Age wells were even more numerous, and located closer to houses. They were private wells and were permanent features of the farms. The position of a well within a settlement was determined by that of the house associated with it, and its position

56 Piotrowska 2019

57 Carsten, Hugh Jones 1995: 8. relative to the house became more or less fixed. ${ }^{58}$ What is more, there is archaeological and historical evidence for the existence of communal public wells, which became increasingly numerous during the Middle Ages and later on. ${ }^{59}$

In the case of settlements of the Przeworsk culture where a small number of wells were discovered, or when they were concentrated in one area, it can be assumed that they were shared wells. At this point, it is also worth mentioning that common wells which were a source of water for the inhabitants, were sometimes located at the central point of the settlement. A perfect example of such a settlement from the Roman period is the site at Mąkolice. ${ }^{60}$ Social life flourished next to such a well. The settlement's inhabitants met there during their daily activities. The great social significance of these features as meeting places should be emphasized. ${ }^{61}$ According to ethnographic sources women usually went to the well to fetch water, less commonly men. ${ }^{62}$ The presence of the vessels used to draw the water found at the bottom of the wells was consequently explained by W. Hensel as caused by the inattention of women absorbed in daily gossip whilst drawing water from the well ${ }^{63}$ (Fig. 7).

58 Groenewoudt et al. 2013.

59 Groenewoudt 2019: 75.

60 Kot, Piotrowska 2016; Piotrowska 2019: 131-133.

61 Piotrowska in press.

62 Siemion 2002: 172.

63 Hensel 1987: 57. 


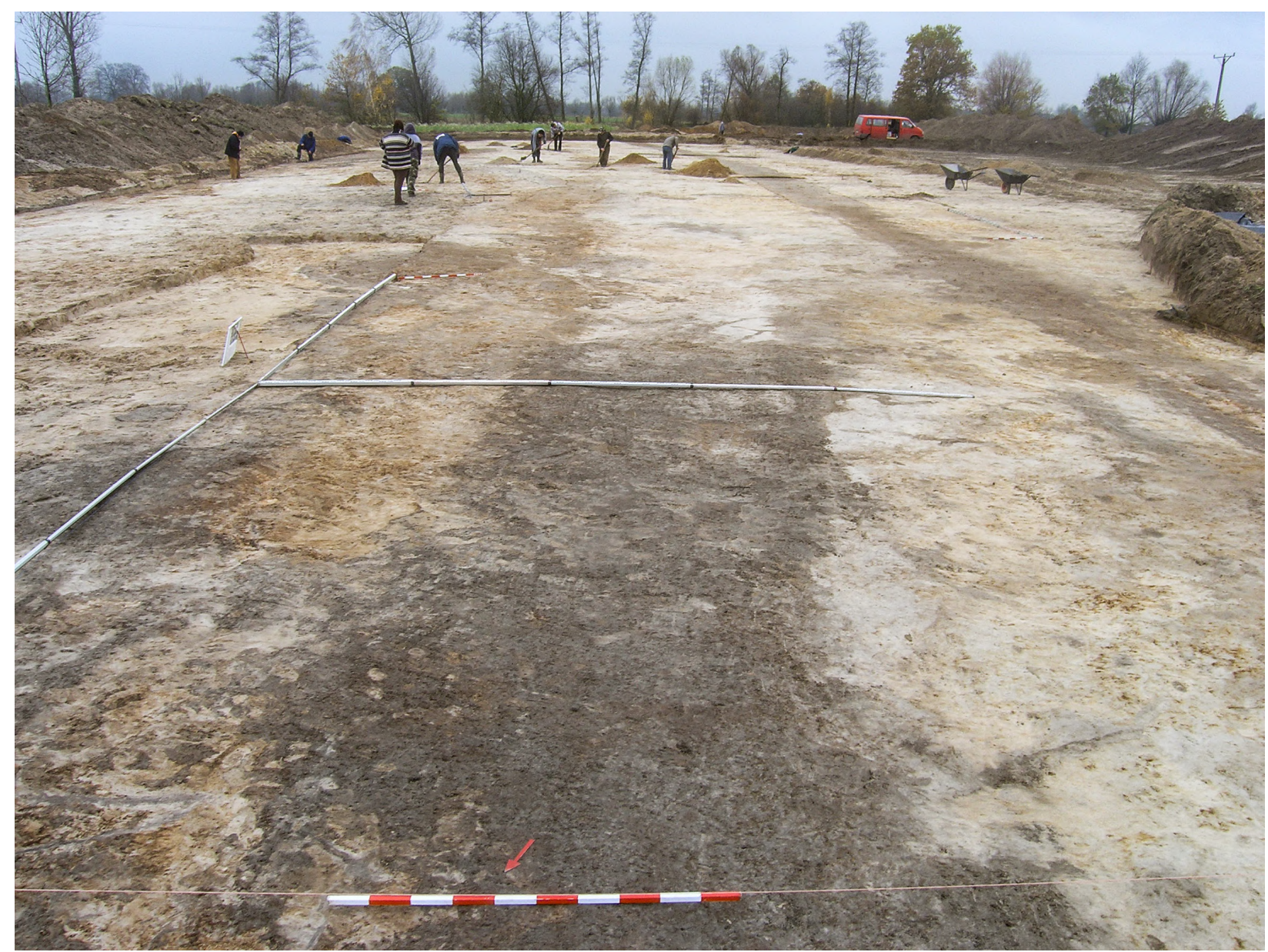

Fig. 14. Kwiatków 11/20, Brudzew commune.

Feature no. 2540 located next to the well no. 2581 (phot. E. Schellner)

The space around the well was a central place in rural space and in small towns until the first half of the 20th century. Until that date, these features were divided into private wells and communal water points. ${ }^{64}$ The well belonged to the basic facilities of the farm. Interestingly, until the 19th century, there was a custom existing in Greater Poland of building one, commonly shared well in the village. ${ }^{65}$ So, shared facilities existed alongside private wells on single farms. It is known from the ethnographic sources that there existed some benchmarks for construction of the well, for example it was supposed to be dug at the boundary of the farm so that others in need could use it while passing by. ${ }^{66}$

A well within the settlement may be common property, but there are also wells which cannot be clearly assigned to individual farms. The number of wells assigned to individual houses may

64 Drożdż, Caputa 2003: 353, 354

65 Burszta 1964: 103, 104.

66 Józefów-Czerwińska 2017: 135. indicate the number of private farms. Homesteads individual farms could have been the smallest social unit "which shaped and ensured coexistence". ${ }^{67}$ Probably between purely private and shared wells there were water points with an indirect function, which belonged to the nearest household, but were also used by other residents of the settlement.

A problem of interpretation also exists in the case of wells discovered to the west of present-day Polish lands. It is mainly due to a lack of information about wells were used only within individual farmsteads, or were common features. The location of the wells within sites shows that they were mainly located in the peripheral part of the settlement, outside of the high-density residential area ${ }^{68}$ Some settlements excavated in Germany (e.g. Barhorst, Berlin-Kaulsdorf, Berlin-Marzahn, Gielde) are distinguished by the concentration of wells outside the centers of the inhabited area. On this basis, it can be concluded that not every house 


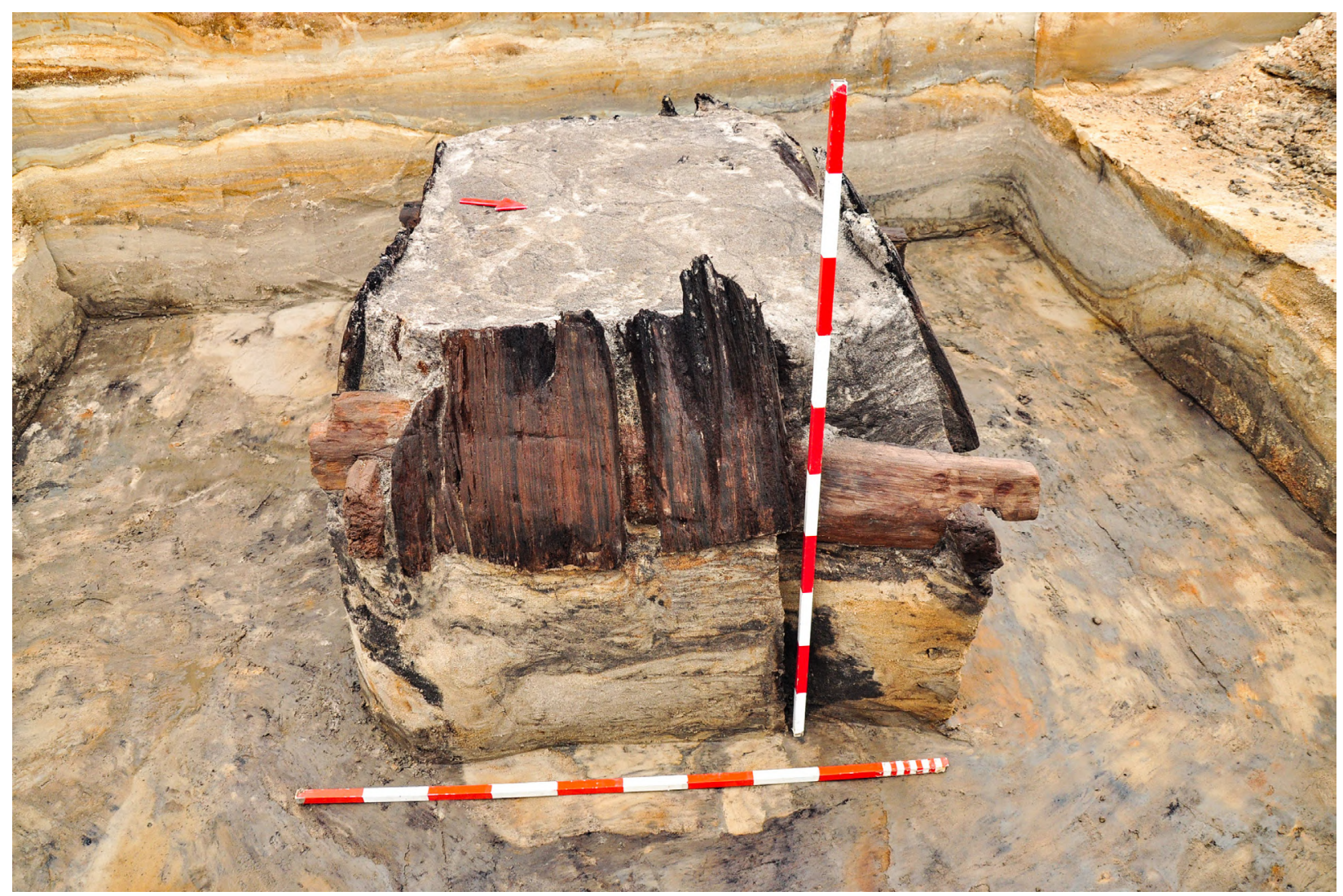

Fig. 15. Kwiatków 11/20, Brudzew commune. Well no. 5573 (phot. E. Schellner)

had its own well, but some wells were common shared features. ${ }^{69}$ Some sites, for example like the recently published settlement in Wustermark, were characterized by a concentration of wells outside the centre of the inhabited area. ${ }^{70}$ On this basis it can be concluded that not every house had its own well, but that points for drawing water were shared. Homesteads shared communal facilities, which could be wells. At Flögeln-Eekholtjen not every farmstead had its own well, but a concentration of these features was discovered in the eastern part of the site. ${ }^{71}$ Feddersen Wierde is an example of a large settlement with many households, where only three artificial wells were discovered, which had to be shared: common wells. ${ }^{72}$ At the site Hjemsted, it was noticed that in the fences surrounding the adjacent longhouses there were gaps, which may indicate the shared use of wells. ${ }^{73}$

Ethnographic sources indicate that where there were no rivers, a well was dug, which was

69 Gaude $1995 \cdot 112$

70 Fisher-Schröter 2019: 73, 74.

71 Zimmermann 1992: 292.

72 Haarnagel 1979: 168.

73 Ethelberg 1986: 21. then used by one or several farms. ${ }^{74}$ Sometimes wells dried up and this could result in a situation whereby a single common well, serving several farms, allowed only the person who had risen first in the morning, to draw water. The people arriving later at the well had to wait for it to fill with water again. ${ }^{75}$ When there were only one or two wells in the village, inhabitants had to queue for water. ${ }^{76}$ Perhaps such situations were avoided at the site in Kwiatków by digging many wells, which given the hydrological conditions governing this settlement was not a big problem. The groundwater level was high and stable, and the digging of wells was facilitated by the sandy ground. ${ }^{77}$

Common wells were distinctive features of older rural neighbourhoods, and well agreements were and still are a common and important part of the use of shared wells. According to ethnographic sources, for example, strangers who were passing through the village could use private wells to draw water for themselves and for their animals, but local strangers could only use a well which was not

\footnotetext{
74 Blin-Olbert 2011: 52; Udziela 1994: 29.

5 Blin-Olbert 2011: 56, 57.

Siemion 2002: 172.

77 See Twardy 2016; Piotrowska 2019 in press.
} 
fenced in, and located in a field. Moreover, a private well could be shared only with the permission of the farmstead owner. The right to draw water from someone else's well was only extended to those persons who had contributed to the building of the well, even though they may only have had a small share of the work, and still contributed to its proper maintenance. ${ }^{78}$ The location of Kwiatków, on the Amber Route and numerous imports from Roman Empire found on the site, indicate contacts with distant areas. It cannot be excluded that the settlement was visited by "strangers" traveling along this ancient trade road. Perhaps some of the wells served people passing through Kwiatków.

One of the wells discussed here (feature 2581) is an example of a common water provision facility, but probably was used for watering livestock which was held within the settlement. Confirmation of such a hypothesis could be the discovery of a trough in the vicinity of this well for watering animals. ${ }^{79}$ As indicated by ethnographic analogies, animal troughs were placed next to wells. These are features which leave only faintly visible traces during archaeological excavation. One find which could be interpreted as a drinking-trough for animals, was discovered in a well in Stickenbüttel. It had the form of a gutter made out of one piece of oak $\log$. Wells were probably divided into those for use by animals and by people ${ }^{80}$ (Fig. 12, Fig. 13). Wooden troughs were still in use in the last century, usually placed next to the well. ${ }^{81}$

It is worth noting that in the vicinity of well 2581, a large feature was discovered, which may be the remains of a ditch in which drinking water for animals was collected (Fig. 14). One post hole was also discovered next to it. Pits located near wells and interpreted as the remains of drinking troughs were discovered at the Witów site, and the basis for such an interpretation of these features were ethnographic analogies..$^{82}$ There was a ditch used for watering cattle at Flogeln Eekholtjen ${ }^{83}$ which was over $200 \mathrm{~m}$ long. Not only did it provide water for animals, but it also acted as a kind of border. This latter proposition is suggested by the fact that traces of the cattle were only found on one side of the ditch. ${ }^{84}$ This ditch was situated on the edge of the settlement, and there is no analogy

78 Świątek 1896: 224.

79 Piotrowska in press.

80 Erixon 1930: 200.

81 Burszta 1964.

82 Tyszler, Nierychlewska 2018: 123.

3 Zimmermann 1992: 48, Abb. 18.

84 Zimmermann 1992: 296, 297, Abb. 237. to it, perhaps due to the peripheral location of such features to the inhabited area. Drinking ponds for cattle are known from archaeological sites..$^{85}$ Rainwater could have been collected in these features as well as water draw from wells.

In this part of zone A1, its eastern area, there were also other features that could be interpreted in a similar way to well 2581, which is presented here in more detail. Perhaps well 5576 may also have been used to provide water for animals (Fig. 15). There was very little pottery in its fill, as was the case in feature 2581. It cannot be excluded that other wells from this part of the site also had a similar function, however, additional features of the Przeworsk culture were discovered in their vicinity, such as hearths, utility pits or post-holes, as well as the fill of these features which furnished much more pottery.

It cannot be excluded that in the case of well 2581 , it was also associated with the nearest half-dugout (feature 2590 with its own private well 2555 ), and at the same time this well was commonly used to supply water for domesticated animals.

When one looks at the plan of zone A1, the hypothesis that well 2581 was used for the watering of animals can be considered as highly possible. It cannot be ruled out that the remaining wells located in the extremity of this Przeworsk settlement, away from other features of the Przeworsk culture and the zones intensively exploited by its inhabitants, were also connected with providing animals with access to water (the wells from eastern part of zone A1). Perhaps cattle were held in the peripheral zones of the settlement. If cattle were supported by the settlement, the inhabitants of Kwiatków needed much more water than only for its people.

Among mammals cattle prevailed in the material analyzed from the settlement. A palynological analysis of the material taken from well 2581 indicates deforestation, the appearance of open areas, an increase in grasses, and the presence of indicators of grazing animals. ${ }^{86}$ Pigs, goats and sheep were raised too, but to a lesser extent. ${ }^{87}$ The needs of herbivorous animals were not all the same, so probably the breeding requirements of the latter may indicate that some wells could be used for watering sheep. A surrounding dry environment,

85 See Arnoldussen 2008: 17.

86 The palynological analysis is part of the grant DEC-2015/16/5/HS3/00241 financed by the National Science Center. The analysis was done by dr Katarzyna Korzeń, and the results were consulted with prof. Krystyna Milecka from Adam Mickiewicz University in Poznań.

87 Waszczuk 2016: 348. 


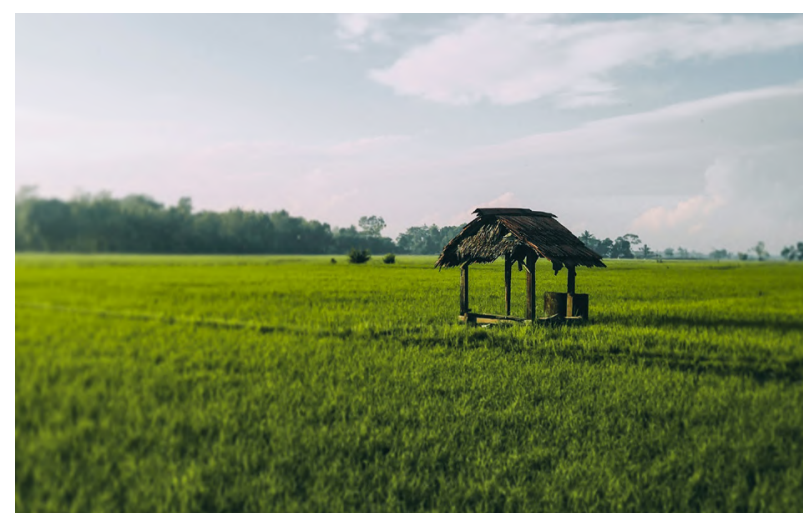

Fig. 16. Well in the meadow with a trough (https://unsplash.com/photos/_wTLpjsU8WA)

distant from water supplies of water, create the most appropriate conditions for these animals. Sheep, one of the principal domesticated species, is an animal which does not occur in the wild in Central Europe, requires certain conditions for its development. Archaeozoological analyses revealed that the health of sheep from the settlement in Kwiatków, assessed only on the basis of possible pathological changes in the bones, was relatively good, which may indicate the broad knowledge of the shepherds in this field, and their adaptation of the environment to the needs of these animals. ${ }^{88}$ Farming these animals required knowledge and experience. ${ }^{89}$ The inhabitants of Kwiatków whom kept sheep probably were acquainted with the needs of their animals on the basis of observation and knowledge transferred from generation to generation. ${ }^{90}$ Sheep are particularly susceptible to infection from Fasciola hepatica, which occurs mainly on plants in the vicinity of water reservoirs. ${ }^{91}$ The threat of parasite infestation during watering from natural reservoirs and the possibility of using wells exclusively for watering sheep was indicated by the archaeozoological analysis of the remains from the site. ${ }^{92}$ As the author of this analysis writes: "Perhaps the then breeders, realizing this fact, dug at least some of the wells in order to ensure the good health of the livestock" ${ }^{93}$ It is necessary to water sheep frequently during the dry winter months, and wells provide water which is less cold in winter, whilst in summer it is fresher than sources of open water. ${ }^{94}$

88 Waszczuk 2016: 349.

89 Sobisiak 1964: 185.

90 See Waszczuk 2016

91 Oczapowski 1840: 320; Sobisiak 1964: 197.

92 Waszczuk 2016; Oczapowski 1840: 256.

93 Waszczuk 2016: 350.

94 Löhner 1839: 36.
An alternative to the cowshed is keeping cattle under the open sky in a fenced area. Such a fence may leave archaeological traces, such as a row of post-holes. In other cases a "fence" could be constructed from branches or saplings, which leave no archaeological trace behind. Other livestock were grazed in woods, and animals could be left to winter outside, even pigs (outwintering). Sheep, although quite delicate, can also winter outdoors. In Iceland, sheep spend the whole year outdoors. Horned cattle and other livestock can be outwintered in northern and central Europe..$^{95}$ In the areas of the southern Slavic lands, it was customary to leave cattle under the open sky in summer and in winter, and sheep were especially bred in this way. Sometimes they were kept within a space bordered by a fence. ${ }^{96}$ In winter, water was sourced from a well or from a river, in spring several times a day because animals drink a lot at this time of the year. ${ }^{97}$ For example sheep drink much more, and they have to be given water twice a day when it's cold. ${ }^{98}$ Access to water, especially in the winter, may be difficult. The Warta, in the vicinity of Kwiatków during the Roman Period, was characterized by a multi-channel system which probably did not facilitate access to flowing waters for grazing animals. ${ }^{99}$

Cattle were kept in a shed without a roof. ${ }^{100}$ According to ethnographic sources, cattle and sheep grazed in the villages on common pastures, sheep on drier areas and cows on wetter. ${ }^{101}$ In Kwiatków there were no traces of fences or buildings that could clearly be considered as sheds, therefore it should be concluded that livestock could be kept outside and the well was located directly at the place where the animals were kept within the settlement, which was the most convenient arrangement (Fig. 16, Fig. 17).

Wells located at the edge of the settlement site and associated with watering animals were recorded, among other examples, in the case of the Przeworsk culture site in Witów. ${ }^{102}$ It is possible that sheep breeding, despite the dominance of cattle, could be of high significance for the settlement's inhabitants. This is indicated by the quite good condition of these animals, which must

95 Zimmermann 1999: 308, 310.

96 Moszyński 1967: 110, 111.

97 Siemion 2002: 172.

98 Grosser 1954: 299.

99 See Twardy 2016: 23; Twardy et al. 2017: 14.

100 Brückner 1938: 134.

101 Nowosz 1976: 217, 218, 220.

102 Tyszler 2018: 164. 


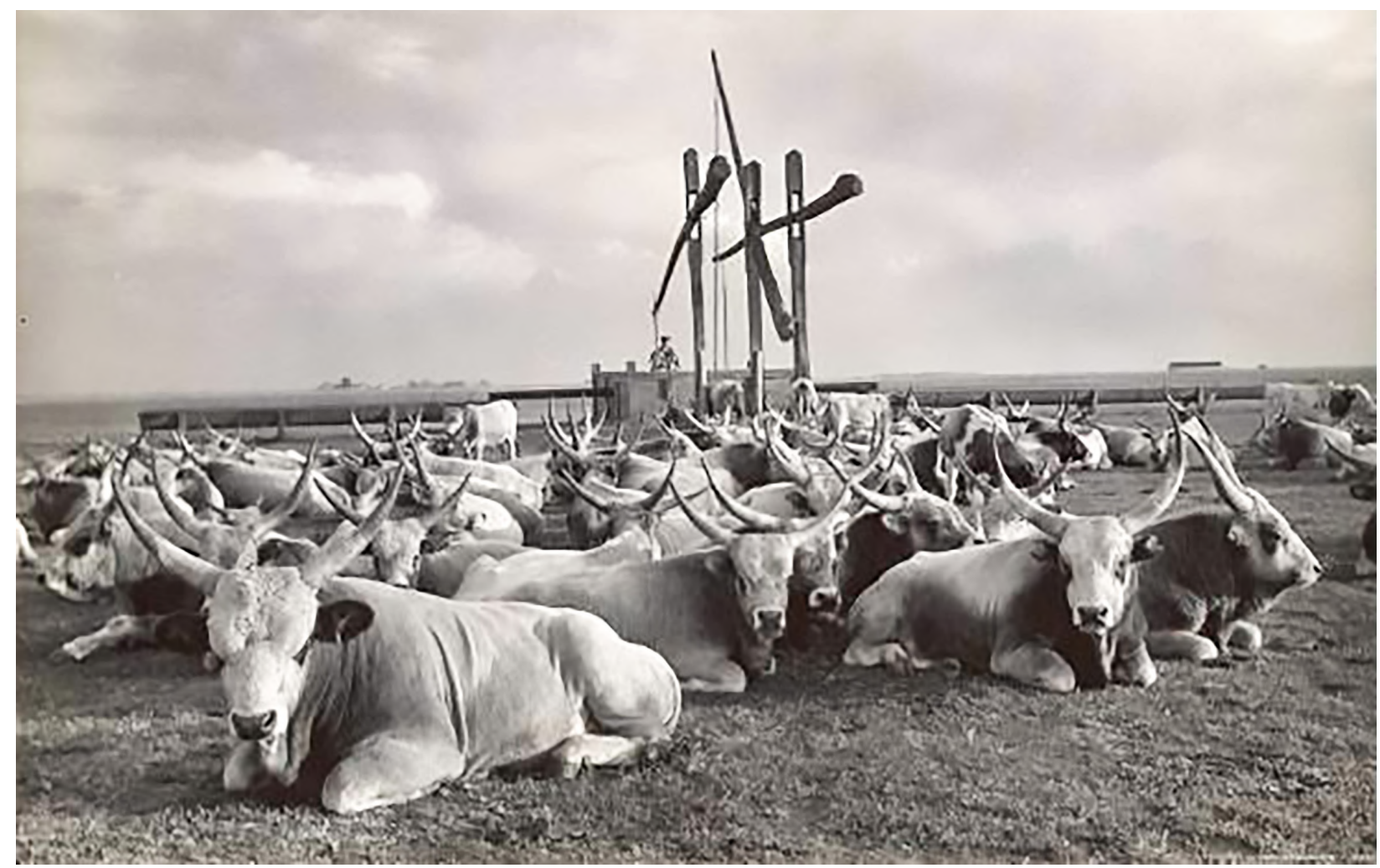

Fig. 17. Cattle gathered around the well, waiting for the troughs to be filled in with water (https://www.google.com/search?q=well+in+the+field+for+animals\&source=lnms\&tbm=isch\&sa=X\&ved= 0ahUKEwjXspuoqqbkAhVjkosKHQTIAdgQ_AUIESgB\&biw=1366\&bih=655\#imgrc=a1FpMh9bWPVEzM)

have been a result of knowing the needs of the said ruminants. Perhaps this was due to some earlier, Celtic influences connected with the location of the site, immediately bordering on Kuyavia, on the Amber Route. These areas could have been visited by the Celts, in such case it might have been due to their location at that ancient, long-range exchange corridor. ${ }^{103}$ It is worth noting that the bone material from Kuyavia has a different structure than that from other regions. The relative quantity according to species composition of the animal bones recovered from Kuyavia resembles the structure of the materials found in Celtic settlements, which is typified by the large proportion of sheep and goats. In Manching, the percentage of small ruminants is comparable to that in Kuyavia, which indicates the influence of Celtic economic tradition on the structure of farming. A large percentage of bones of small ruminants is not typical of other areas inhabited by the Przeworsk culture. ${ }^{104}$

During the development of the Przeworsk culture, the area in which Kwiatków lies was inhabited by a population that has been identified with the Lugian Federation, known from ancient sources,

103 See Olędzki 1997; Woźniak 1996.

104 Makiewicz 1977: 112, 117, 123, 124, 126. which, according to some researchers, was created by the Celtic population of the area, who also brought together other non-Celtic tribes. ${ }^{105} \mathrm{~A}$ cemetery located near Koło, north of Kwiatków, also on the Warta River, yielded among other things, burials with features reminiscent of the funeral rites practiced by the La Tène Culture. ${ }^{106}$ It is important to remember that the artefacts discovered in Kwiatków included some items of Celtic provenance (beads or knobbed "money" rings). ${ }^{107}$

Absolute and relative chronology and the results of geochemical analyses

Small buildings based on six posts: dugouts and half-dugouts, occur at the end of the early Roman Period, and this is precisely the chronology that was determined in the course of the dendrochronological analysis for feature $2590 .{ }^{108}$ A relationship of well 2555 with that of the half-dugout

105 Michałowski 2002: 17; see Strzelczyk 2005.

106 Machajewski 2008: 112.

107 See Rzepecki, Kot, Piotrowska 2016.

108 Michałowski 2011: 101; Kot, Piotrowska 2016: 108. 
is beyond any reasonable doubt, and the dating of the pottery obtained from this well to the Roman Period, correlates with the dendrochronological dates obtained for the remains of the lower parts of posts set in the earth. The chronology of this "complex" can be placed in phase B2b of the Roman Period. Consequently the period in which the feature (2581)was in use has been determined to lie in the years after $\mathrm{AD} 138$ (i.e. after the earliest date in which any tree used for the construction of the casing of this well was cut down. Considering the dates obtained for the pottery from the fill of this feature, it seems that the well was probably in use after phase B2b of the Roman Period and possibly until the end of the early Roman Period, as indicated by the chronology of the pottery. It was probably used as a well a bit later than feature 2555 . It is, of course, possible that the time in which both these wells were in use overlapped. Maybe later the inhabitants of half-dugout 2590 also used well 2581 which was located not that far from this feature.

The fill of these two features could have then have arrived at the well as either waterborne wash brought from the slopes of the moderate hillock found in the middle of the archaeological site, or as surface water wash combined with aeolian action. The sediments are of a specific layered structure, but the layers assume a post-sedimentary deformed composition. The deformation of the layers occurred under the influence of a continuous collapse of the formations filling the well. The deformation processes happened gradually at first, and did not cause the continuity of the layers to break, but led to them being shaped in a concave manner which generally corresponded to the shape of the well. It is possible that, during the shaping of the fill of the wells, aeolian and gravitational processes worked in tandem with the fluvial processes. In such case, however, it would be necessary to assume that the fillings of the wells had been formed at the time of the inhabitation of the site or immediately after the settlement had been deserted, under the conditions of a fully destroyed plant cover in this area. After the retreat of settlement activity, and the regeneration of vegetation, the aeolian and gravitational processes were fully halted. ${ }^{109}$

Similar values of geochemical composition, and percentage share of individual mineral fractions as was the case in one well reoccur on its floor, and in the other well in the upper part of the sampled sediment sequences. This probably reflects the different times in which these wells were

109 Piotrowska, Okupny, Twardy, Forysiak 2019. filled. The filling of these two wells was not a simultaneous event. ${ }^{110}$ Summing up, both the relative chronology based on pottery analysis, and the absolute dating based on tree ring analysis, as well as specialized geochemical and lithological research, lead us to conclude that well 2581 is slightly younger than feature 2555 . The process of the filling of well 2555 took place earlier than was the case for feature 2581. Despite the considerable differences between these features, such as location within the settlement, and their social function, it can be concluded that both wells were abandoned after cessation of their use, and they were not intentionally back-filled by the inhabitants, but instead underwent slow, natural filling processes. Overall, the geochemical and lithological analyses show that the processes responsible for filling both wells did not take place at the same time.

\section{Conclusions}

It seems clear that the features described in this article were primarily wells, but they probably had different functions, and hence their different location within the layout of the settlement. This was confirmed by a detailed analysis of the quantity and character of the artefacts, and their deposition level in the context of the two fills. Consequently, one of the wells has been described as "private" connected with the half-dugout, and the other as a "public" well generally accessible, and possibly connected with the watering of animals. The latter feature 2581 was probably a common access well, however, not of such great social importance for the inhabitants of the settlement, (as, for example, was the public well in Mąkolice. ${ }^{111}$ This well was not a central point, where the inhabitants met while drawing water, but probably only a common well to provide water for animals. At the site in Kwiatków, a central well cannot be identified within the whole of the surveyed area. Moreover, most of the half-dugouts had their own wells.

In an agrarian settlement cattle needed more water in winter-time, when the cattle were outdoors or in the byre, than people. Evidence for the use of one well by several farmsteads, and the existence of private wells can be found not only in the archaeological sources, but also in ethnographical ones. ${ }^{12}$ Public wells are still very common (Fig. 18).

110 Piotrowska, Okupny, Twardy, Forysiak 2019: 64.

111 Kot, Piotrowska 2016a; Piotrowska 2019.

112 see Witkoś 1977: 116. 


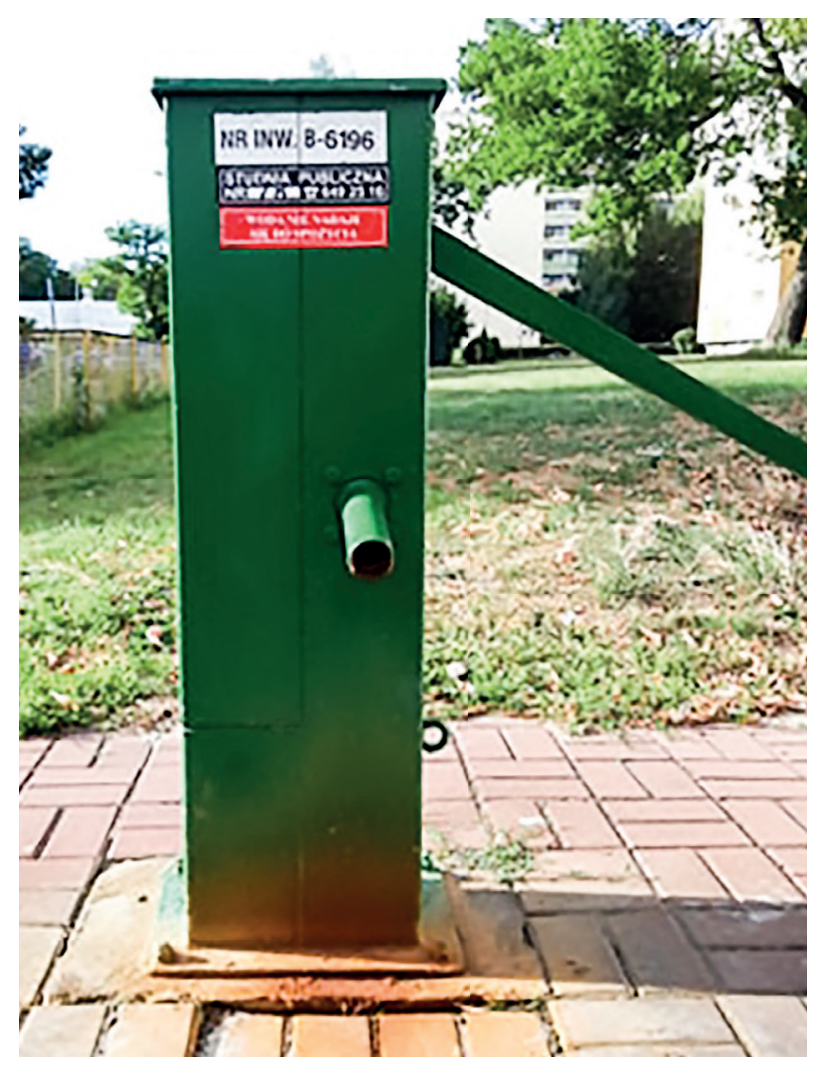

Fig. 18. Modern public well at the residential estate in Lodz (phot. M. Piotrowska)

Wells should be also considered in a social context as a common effort of the settlement's inhabitants, and also as a feature being used by a single farm. Such shared facilities were probably taken care of by the inhabitants who then tried to keep them in the best possible condition. Archaeological sources indicate the cleaning of wells and repairs to their casings, e.g. at the Flögeln site, where repairs to wells have been noticed. ${ }^{113}$ Wells tended to bring communities together, but they also might have been the source of tensions. Perhaps formal rules existed regarding access to water. ${ }^{114}$

Through interdisciplinary research, it has proved possible to identify some differences in the chronology of both features which have been analysed in this paper. Despite slight differences in the dating of both of the wells studied, it can be assumed that within this settlement they functioned as one a private, and the other a public well. So well no 2581 could have belonged to the nearest household, and at the same time been a shared facility with the other inhabitants providing water for animals.

113 Zimmermann 1992: 289.

114 Hastrup 2013: 62, 63.
Literature

Arnoldussen S. 2008. Appendices to A Living Landscape: Bronze Age Settlement Sites in the Dutch river area (c. 2000-800 BC), Leiden ( $\mathrm{PhD}$ thesis).

Blin-Olbert D. 2011. Zdobywanie i użytkowanie wody we wsiach i miasteczkach poludniowo-wschodniej Polski. Biuletyn Stowarzyszenia Muzeów na Wolnym Powietrzu w Polsce 12, 49-59.

Brückner A. 1938. Encyklopedia Staropolska. Warszawa: Księgarnia Trzaski, Everta i Michalskiego.

Burszta J. (red.). 1964. Kultura ludowa Wielkopolski, tom II. Poznań. Wydawnictwo Poznańskie.

Carsten J., S. Hugh-Jones. 1995. Introduction: about the house - Lévi-Strauss and beyond. W: J. Carsten, S. Hugh-Jones (eds.), About the house. Levi-Strauss and beyond, Cambridge, $1-46$.

Czarnecka K. 2007. Oblin. Ein Gräberfeld der Przeworski-Kultur in Südmasovien. (= Monumenta Archaeologica Barbarica 14), Warszawa: Państwowe Muzeum Archeologiczne w Warszawie, Fundacja Monumenta Archaeologica Barbarica.

Dąbrowska T. 1988. Wczesne fazy kultury przeworskiej. Chronologia-zasięg-powiazania. Warszawa: PWN.

Drożdż A., Z. Caputa. 2003. Studnie w krajobrazie kulturowym polski na podstawie Polskiego Atlasu Etnograficznego. W: A. Jankowski, U. Myga-Piątek, G. Jankowski (eds), Problemy ochrony środowiska i ksztaltowania krajobrazu Górnego Ślaska na tle doświadczeń z innych regionów Polski, Sosnowiec, 353-366.

Dzięgielewska M., M. Kulczyńska. 2008. Ciebłowice Duże. Ein Gräberfeld der Przeworsk-Kultur im südwestlichen Masowien. (= Monumenta Archaeologica Barbarica 13), Warszawa: Państwowe Muzeum Archeologiczne w Warszawie, Fundacja Monumenta Archaeologica Barbarica.

Erixon S. 1930. Om brunnar, Fataburen, 172-218.

Ethelberg P. 1986. Hjemsted - en gravplads fra 4. \& 5. årh. e. Kr. Skrifter fra Museumsrådet for Sønderjyllands amt 2, Haderslev.

Fischer-Schröter P. 2019. Die germanische Siedlung Wustermark 23, Lkr. Havelland, Materialien zur Archäologie in Brandenburg 11.

Forysiak J. 2005. Rozwój doliny Warty miedzy Burzeninem $i$ Dobrowem po zlodowaceniu Warty. Acta Geographica Lodziensia 90, 1-116. 
Gaude B. 1995. Brunnenanlagen der römischen Kaiserzeit und frühen Völkerwanderungszeit (4.-5. Jahrhundert) in Norddeutschland [unpubl. M.A. thesis Univ. Kiel 1995].

Gilewska S. 1986. Podziat Polski na jednostki geomorfologiczne. Przegląd Geograficzny 58 (1-2), 15-40.

Godłowski K. 1981. Kultura przeworska. Budownictwo. W: J. Wielowiejski (ed.), Prahistoria ziem polskich, $t$. V. Późny okres lateński i okres rzymski. Wrocław-Warszawa-Kraków-Gdańsk: Zakład Narodowy im. Ossolińskich, Wydawnictwo Polskiej Akademii Nauk, 105-106.

Groenewoudt B., J. Benders. 2013. Private and shared water facilities in rural settlements and small towns. Archaeological and historical evidence from the Netherlands from the medieval and post-medieval periods. W: Proceedings Ruralia in 2011, Götzis, 245-262.

Groenewoudt B. 2019. De watervoorziening op de zandgronden Ruimtelijke patronen, historische ontwikkelingen, achtergronden. Tijdschrift voor Historische Geografie 4E (2), 74-88.

Grosser M. 1954. Krótkie i bardzo proste wprowadzenie do gospodarstwa wiejskiego. Wrocław: Zakład imienia Ossolińskich.

Haarnagel W. 1979. Die Grabung Feddersen Wierde. Die Ergebnisse der Ausgrabungen der vorgeschichtlichen Wurt Feddersen Wierde bei Bremerhaven in den Jahren 1955 bis 1963. Feddersen Wierde 2. Wiesbaden: Steiner.

Hastrup K. 2013. Water and the Configuration of Social Worlds: An Anthropological Perspective. Journal of Water Resource and Protection 5, 59-66.

Hensel W. 1987. Stowiańszczyzna wczesnośredniowieczna. Zarys kultury materialnej. Warszawa: PWN.

Jadczykowa I. 1981. Budownictwo mieszkalne ludności kultury przeworskiej na obszarze Polski. Prace i Materiały Muzeum Archeologicznego i Etnograficznego w Łodzi. Seria Archeologiczna 28, 109-247.

Jankuhn H. 2004. Wprowadzenie do archeologii osadnictwa. Poznań: Poznańskie Towarzystwo Przyjaciół Nauk.

Józefów-Czerwińska B. 2017. Zabobonem nazwano...O wierzeniach, wartościach $i$ dawnych przekonaniach mieszkańców polsko-białoruskiego pogranicza w ich zwiazkach z przeszłościa. Warszawa: Wydawnictwo Trzecia Strona.

Jurkiewicz B., H. Machajewski. 2006. Osadnictwo kultury przeworskiej z przełomu er oraz późnego okresu rzymskiego i wczesnej fazy okresu wędrówek ludów. W: L. Czerniak, J. Gąssowski (eds), Osada wielokulturowa w Jankowie, gmina Piątek, województwo tódzkie (= Via Archaeologica Pultuskiensis 1). Pultusk: Instytut Archeologii Uniwersytet Gdański, Instytut Antropologii i Archeologii Akademii Humanistycznej im. Aleksandra Gieysztora, 109-218.

Kirsch E. 1986. Germanische Kastenbrunnen von Berlin-Kaulsdorf. Zeitschrift für Archäologie 20, 103-119.

Klatkowa H. 1972. Paleogeografia Wyżyny Łódzkiej $i$ obszarów sąsiednich podczas zlodowacenia warciańskiego. Acta Geographica Lodziensia 28.

Kobyliński Z. 1988. Struktury osadnicze na ziemiach polskich u schytku starożytności i w początkach wczesnego średniowiecza. WrocławWarszawa-Kraków, Gdańsk: Ossolineum.

Kossack G. 1997. Dörfer im Nördlichen Germanien vornehmlich aus der römischen Kaiserzeit. Lage, Ortsplan, Betriebsgeflüge und Gemeinschaftsform. München: Verlag der Bayerischen Akademie der Wissenschaften.

Kot K. 2016. Ceramika z okresów przedrzymskiego, rzymskiego i wędrówek ludów. W: S. Rzepecki (ed.), Wielokulturowy kompleks osadniczy ze stanowiska Kwiatków 11/20, gm. Brudzew. Strefy A1 i A2. Łódź: Instytut Archeologii Uniwersytetu Łódzkiego, Fundacja Uniwersytetu Łódzkiego, Łódzka Fundacja Badań Naukowych, 141-274.

Kot K., M. Piotrowska. 2016. Chronologia i zagospodarowanie stref A1 i A2 w okresach przedrzymskim, rzymskim $i$ wędrówek ludów. W: S. Rzepecki (ed.), Wielokulturowy kompleks osadniczy ze stanowiska Kwiatków 11/20, gm. Brudzew. Strefy A1 i A2. Łódź: Instytut Archeologii Uniwersytetu Łódzkiego, Fundacja Uniwersytetu Łódzkiego, Łódzka Fundacja Badań Naukowych, 287- 302.

Kot K., M. Piotrowska. 2016a. Mąkolice, stan. 15, gm. Glowno. Przyczynek do badań nad zagospodarowaniem przestrzennym osad ludności kultury przeworskiej. W: S. Kadrow (ed.), $R a$ port 11. Warszawa, 107-122.

Krąpiec M. 2016. Wyniki analiz dendrochronologicznych próbek drewna z badań prowadzonych na stanowisku Kwiatków 11, gm. Brudzew. W: S. Rzepecki (ed.), Wielokulturowy kompleks osadniczy ze stanowiska Kwiatków 11/20, gm. Brudzew. Strefy A1 i A2. Łódź: Instytut Archeologii Uniwersytetu Łódzkiego, Fundacja Uniwersytetu Łódzkiego, Łódzka Fundacja Badań Naukowych, 359-366.

Krzyszowski A. 2012. Starożytne studnie ze Stugocinka, stan. 13. W:A. Jaszewska(ed.), Znajdawniejszych dziejów. Grzegorzowi Domańskiemu 
na pięćdziesięciolecie pracy naukowej. Zielona Góra 2012: Wydawnictwo Fundacji Archeologicznej,143-158.

Leube A. 2009. Studien zu Wirtschaft und Siedlung bei den germanischen Stämmen im nördlichen Mitteleuropa während des 1. Bis 5./6. Jahrhunderts n. Chr. Römisch-Germanische Forschungen 64.

Liana T. 1970. Chronologia względna kultury przeworskiej we wczesnym okresie rzymskim. Wiadomości Archeologiczne 35 (4), 429-487.

Löhner D.J. 1839. Zasady pielegnowania owiec i znajomości wetny. Dla poczynajacych owczarzów i stug gospodarskich. Lwów: Franciszek Piller.

Machajewski H. 1995. Osada ludności kultury przeworskiej na stanowisku 1 w Kucowie, gm. Kleszczów, woj. Piotrków Trybunalski. Prace i Materiały Muzeum Archeologicznego i Etnograficzneg w Łodzi. Seria Archeologiczna 37-38, 65-137.

Machajewski H. 2008. Nowe kierunki badań nad społecznościami Wielkopolski z okresu od I $w$ n.e. do V/VI $w$ n.e. W: H. Machajewski (ed.), Wielkopolska $w$ dziejach. Poznań: Wydawnictwa Oddziału Wielkopolskiego SNAP, 107-125.

Michałowski A. 2002. Najdawniejsze dzieje miasta i okolic. W: E. Makowiecki, Cz. Łuczak (eds), Dzieje Turku, Poznań: Wydawnictwo WBP, 15-19.

Michałowski A. 2011. Budownictwo kultury przeworskiej. Poznań: Wydawnictwo Poznańskie.

Moszyński K. 1967. Kultura ludowa Stowian. Część I. Kultura materialna. Kraków: Polska Akademia Umiejętności.

Nowakowski W., A. Waluś. 1986. Studnie kultury przeworskiej z ziem Polski. Światowit 36, 43-64.

Nowosz W. 1976. Zajęcia rolnicze $i$ hodowlane. W: M. Biernacka, B. Jaworska-Kopczyńska, A. Kutrzeba-Pojnarowa, W. Paprocka (eds), Etnografia Polski. Przemiany kultury ludowej, tom I. Wrocław-Warszawa-Kraków-Gdańsk: Polska Akademia Nauk, 185-245.

Oczapowski M. 1840. Gospodarstwo wiejskie obejmujace $w$ sobie wszystkie gatęzie przemystu rolniczego teoretyczno-praktycznie wytożone 10. Zasady ogólne hodowli bydlat domowych. Warszawa: S.H. Merzbach.

Olędzki M. 1997. Ogólne uwagi na temat osadnictwa celtyckiego $w$ Polsce. Prace i Materiały Muzeum Miasta Zgierza 2, 155-180.

Petera J. 2002. Vistuliańskie osady dolinne $w$ basenie uniejowskim i ich wymowa paleogeograficzna. Acta Geographica Lodziensia 83, 1-164.
Petera J., J. Forysiak. 2003. The last ice sheet extent in Central Poland. Geological Quarterly 47 (4), 574-578.

Petera-Zganiacz J., M. Piotrowska, J. Twardy, D. Dzieduszyńska, D. Okupny, J. Forysiak, S. Rzepecki. 2019. Environmental conditions as a key factor in the functioning of wells at settlement from the Roman period of the Iron Age. Quoternary International 501, 250-268.

Piotrowska M. 2016. Osadnictwo z okresu przedrzymskiego, okresu wptywów rzymskich $i$ wczesnego okresu wędrówek ludów. Perspektywa źródet nieruchomych. W: S. Rzepecki (ed.), Wielokulturowy kompleks osadniczy ze stanowiska Kwiatków 11/20, gm. Brudzew. Strefy A1 i A2. Łódź: Instytut Archeologii Uniwersytetu Łódzkiego, Fundacja Uniwersytetu Łódzkiego, Łódzka Fundacja Badań Naukowych, 47-138.

Piotrowska M. 2019. Place and importance of wells in settlements of central european communities in late antiquity. An example of the Przeworsk culture from Kwiatków (woj. wielkopolskiel $P L)$. Archäologisches Korespondenzblatt 49 (1), 127-148.

Piotrowska M. 2020. Zaczerpnać wody. Sposoby użtkowania studni w pradziejach na przyktadzie znalezisk zwiazanych z kultura przeworska. W: A. Michałowski, M. Olędzki, K. Kot, M. Piotrowska (eds), Kultura przeworska. Procesy przemian i kontakty zewnętrzne (ebook).

Piotrowska M. in press: Functions of the wells in settlements of the Central European communities representing the Late Antiquity - an example of the Przeworsk culture. Archäologisches Korespondenzblatt.

Piotrowska M., J. Forysiak in press. „Ziemia studzienna"-możliwości i perspektywy badawcze wypetnisko studni na przyktadzie stanowiska Kwiatków 11/20, gmina Brudzew.

Piotrowska M., D. Okupny, J. Twardy, J. Forysiak. 2019. Roman period well fills resulting from using and abandonment in environment of a river valley (Kwiatków site, Central Poland). Studia Quaternaria 36 (1), 55-69.

Rzepecki S. 2016. Wprowadzenie. W: S. Rzepecki (ed.), Wielokulturowy kompleks osadniczy ze stanowiska Kwiatków 11/20, gm. Brudzew. Strefy A1 i A2. Łódź: Instytut Archeologii Uniwersytetu Łódzkiego, Fundacja Uniwersytetu Łódzkiego, Łódzka Fundacja Badań Naukowych, 5-13.

Rzepecki S., K. Kot, M. Piotrowska. 2016. Pod prąd czasu. Kwiatków i okolica w pradziejach. Łódź: Instytut Archeologii Uniwersytetu 
Łódzkiego, Fundacja Uniwersytetu Łódzkiego, Łódzka Fundacja Badań Naukowych, Urząd Gminy Brudzew.

Skowron J. 2014. Osada w działaniu. Osady ludności kultury przeworskiej w Polsce Środkowej od młodszego okresu przedrzymskiego do okresu wędrówek ludów. Poznań: Stowarzyszenie Naukowe Archeologów Polskich Oddział w Poznaniu.

Siemion K. 2002. Woda cudowna, woda zwyczajna. Polska Sztuka Ludowa - Konteksty 56 (1-2), 172-187.

Sobisiak W. 1964. Owczarstwo. W: J. Burszta (ed.), Kultura ludowa Wielkopolski, tom II, Poznań: Wydawnictwo Poznańskie, 185-214.

Stapelfeldt T. 2000. Brunnen im Dutzend. Archäologie in Berlin und Brandenburg 2000, 73-75.

Strzelczyk J. 2005. Wandalowie i ich afrykańskie państwo. Warszawa: Państwowy Instytut Wydawniczy.

Świątek J. 1896. Zwyczaje i pojęcia prawne. Materyały antropologiczno-archeologiczne i etnograficzne 1.

Twardy J. 2016. Przyrodnicze uwarunkowania osadnictwa $w$ strefach A1 i A2 stanowiska Kwiatków (stan. 11, stan. 20), gmina Brudzew (Kotlina Kolska). W: S. Rzepecki (ed.), Wielokulturowy kompleks osadniczy ze stanowiska Kwiatków 11/20, gm. Brudzew. Strefy A1 i A2. Łódź: Instytut Archeologii Uniwersytetu Łódzkiego, Fundacja Uniwersytetu Łódzkiego, Łódzka Fundacja Badań Naukowych, 15-34.

Twardy J., J. Petera-Zganiacz, D. Dzieduszyńska, J. Forysiak. 2017. Analiza warunków przyrodniczych $w$ okolicach stanowisk archeologicznych Kwiatków 11 i 20 (gm. Brudzew) ze szczególnym uwzględnieniem geomorfologii i geologii. Specialist analysis for the grant no. DEC2015/16/5/HS3/00241, financed by National Science Centre [unpubl. report Uniwersytet Łódzki Wydział Nauk Geograficznych Katedra Geomorfologii i Paleogeografii, Łódź 2017].

Tyszler L., A. Nierychlewska. 2018. Ratownicze badania archeologiczne na stanowisku 14-15 $w$ Witowie, pow. tęczyca, woj. tódzkie (trasa autostrady A-1). Via Archaeologica Lodziensis 8, Łódź.
Tyszler L. 2018 Osada kultury jastorfskiej i przeworskiej. W: R. Grygiel, T. Łapińska, P. Papiernik (eds), Ratownicze badania archeologiczne na stanowisku 14-15 w Witowie, pow. Łęczyca, woj. tódzkie (trasa autostrady A-1), Łódź: Wydawnictwo Fundacji Badan Archeologicznych Imienia Profesora Konrada Jażdżewskiego, 31-172.

Udziela S. (ed.) 1994. Ziemia Biecka. Lud polski $w$ powiatach gorlickim i grybowskim. Praca zbiorowa napisana $w$ latach 1889-1895. Nowy Sącz: Sądecka Oficyna Wydawnicza WOK.

Waszczuk K. 2016. Szczątki zwierzęce ze stanowiska 11/20 w Kwiatkowie, gm. Brudzew - strefy A1 i A2. W: S. Rzepecki (ed.), Wielokulturowy kompleks osadniczy ze stanowiska Kwiatków 11/20, gm. Brudzew. Strefy A1 i A2. Łódź: Instytut Archeologii Uniwersytetu Łódzkiego, Fundacja Uniwersytetu Łódzkiego, Łódzka Fundacja Badań Naukowych, 339-358.

Witkoś S. 1977. Bajdy i Moderowka. Warszawa: Państwowe Wydaw. Rolnicze i Leśne.

Zimmermann H. 1992. Die Siedlungen des 1. Bis 6. Jahrhunderts nach Christus von Flögeln-Eekhöltjen, Niedersachsen. Die Bauformen Und Ihre Funktion. Probleme der Küstenforschung im südlichen Nordseegebiet 19.

Zimmermann H.1999. Why was cattle-stalling introduced in prehistory? The significance of byre and stable and of outwintering. W: Ch. Fabech, J. Ringtved (eds), Settlement and Landscape, 301-318.

Aknowledgments

The article is a part of the research project which has been financed from the budget of the National Science Centre granted as part of financing an internship after obtaining a doctoral degree based on decision number DEC-2015/16/S/HS3/00241.

The author is grateful to the Łódzka Fundacja Badań Naukowych for providing materials for the research project number DEC-2015/16/S/ HS3/00241 and the author would like to thank the reviewers for their comments.

Magdalena Piotrowska ORCID 0000-0002-8774-2052 Institute of Archaeology and Ethnology Polish Academy of Sciences Łódź Department piotrowskamagda@op.pl 